\title{
BIOSYNTHESIS OF $\triangle$-AMINOLEVULINATE IN GREENING BARLEY LEAVES VI. ACTIVATION OF GLUTAMATE BY LIGATION TO RNA
}

\author{
by \\ C. GAMINI KANNANGARA, SIMON P. GOUGH, RICHARD P. OLIVER and \\ SØREN K. RASMUSSEN
}

\author{
Department of Physiology, Carlsberg Laboratory, Gamle Carlsberg Vej 10, \\ DK-2500 Copenhagen Valby
}

\begin{abstract}
Keywords: tRNA, RNAase, affinity chromatography, chlorophyllin-Sepharose, HPLC, chlorophyll biosynthesis, glutamyl tRNA, aminoacyl synthetase
\end{abstract}

\begin{abstract}
The components involved in the enzymic conversion of glutamate to $\delta$-aminolevulinate have been separated into three fractions; a Blue Sepharose bound, a chlorophyllin-(or heme) Sepharose bound and an unbound fraction. Combination of these three fractions reconstituted $\delta$-aminolevulinate synthesis from glutamate. Participation of a specific RNA in $\delta$-aminolevulinate synthesis was established by isolating a homogeneous RNA from the chlorophyllin-Sepharose bound fraction and reconstituting $\delta$-aminolevulinate synthesis in the presence of the unbound and Blue Sepharose bound fractions. The RNA involved in $\delta$-aminolevulinate synthesis was purified by high-pressure liquid chromatography and preparative gel electrophoresis. In the presence of the Blue Sepharose bound fraction, ATP and $\mathrm{Mg}^{2+}$, glutamate bound covalently to this RNA. Co(III)-ATP-o-phenanthroline bound to the RNA and strongly inhibited glutamyl-RNA formation, whereas heme and Mg-protoporphyrin at $50 \mu \mathrm{M}$ were only slightly inhibitory. The chlorophyllin-Sepharose bound fraction also contained two other glutamate acceptor RNAs. RNAase A and snake venom phosphodiesterase strongly reduced $\delta$-aminolevulinate synthesis and glutamyl-RNA formation, whereas addition of DNAase or spleen phosphodiesterase was only slightly inhibitory. The RNA became sensitive to the spleen enzyme after phenol extraction of the chlorophyllin-Sepharose bound fraction. E. colitRNA ${ }^{\text {Glu }}$ or wheat germ tRNA did not reconstitute $\delta$-aminolevulinate synthesis when combined with the Blue Sepharose bound and unbound fractions. The RNA involved in $\delta$-aminolevulinate synthesis hybridised to a $3.9 \mathrm{~kb}$ Hind III Pst I restriction endonuclease fragment from the barley chloroplast genome located in the large single copy region $38 \mathrm{~kb}$ from the large subunit gene for RuBP carboxylase and $12 \mathrm{~kb}$ from the inverted repeats. Glutamate 1-semialdehyde aminotransferase was labelled during ${ }^{35}$ S-incorporation into greening barley leaves but not during incorporation into isolated plastids. It is suggested that an NADPH-dependent dehydrogenase involved in the reduction of glutamyl-RNA to glutamate 1-semialdehyde is present in the Blue Sepharose bound fraction.
\end{abstract}

\section{INTRODUCTION}

$\delta$-Aminolevulinate is synthesised from glutamate in the stroma of greening plastids $(5,6$, $10,13,17)$. The components required for $\delta$-aminolevulinate synthesis from glutamate in barley and in Chlamydomonas have been separated previously into three fractions by serial affinity chromatography using Cibacron blue-Sepharose, Procion red-Agarose and heme-Sepharose $(21,22)$. The combination of the Blue Sepharose and the heme-Sepharose bound fractions converted glutamate into glutamate l-semialdehyde using ATP, $\mathrm{Mg}^{2+}$ and NADPH as cofactors. Glutamate 1-semialdehyde aminotransferase,

Abbreviations: $\delta$-ALA-RNA = RNA involved in $\delta$-aminolevulinate biosynthesis; bp = base pairs; $\mathbf{k b p}=$ kilobase pairs; $\mathrm{PEI}=$ polyethylenimine; Tris = trishydroxylmethyl aminomethane. 
which was not retained by the affinity columns, catalysed the last step in $\delta$-aminolevulinate synthesis. In this paper we show that the component binding to heme-Sepharose also binds to chlorophyllin-Sepharose and is an RNA which activates glutamate with the help of an aminoacyl ligase present in the fraction binding to the Cibacron blue-Sepharose. We also show that glutamyl-RNA formed in this reaction precedes glutamate 1-semialdehyde in the biosynthesis of $\delta$-aminolevulinate. Some of these results have been briefly presented (24).

\section{MATERIALS AND METHODS}

\subsection{Chemicals and enzymes}

Chlorophyllin, polyethylenimine cellulose (medium mesh), phosphodiesterase I (type VII, Crotalus atrox venom), phosphodiesterase II (type I-S, bovine spleen), ribonuclease A (type IIA, bovine pancreas), ribonuclease $T_{1}$ (grade IV, Aspergillus oryzae), deoxyribonuclease I (type III, bovine pancreas) and Staphyloccocus aureus protease (type XVII, strain V8) were obtained from Sigma, USA. Alkaline phosphatase (calf intestinal) and polynucleotide kinase $\left(\mathrm{T}_{4}\right.$ amN81 pseII infected $\mathrm{E}$. coli) were obtained from Boehringer Mannheim, W. Germany. N-ethyl-N'-(3-dimethylaminopropyl)-carbodiimide hydrochloride was obtained from Fluka AG, Switzerland. Dithiothreitol and trioctylmethylammonium chloride (Adogen 464) were obtained from Serva, W. Germany. L-glutamate- $\mathrm{U}-{ }^{14} \mathrm{C}\left(275 \mathrm{mCi} \times \mathrm{mmole}^{-1}\right)$ and ${ }^{3} \mathrm{H}(\mathrm{G})$ glutamate (22 Cixmmole ${ }^{-1}$ ) were obtained from Amersham, UK. ${ }^{35}$ S-Methionine ( $1005 \mathrm{Ci} \times \mathrm{m}$ mole $\left.{ }^{-1}\right),{ }^{32} \mathrm{P}-\gamma-\mathrm{ATP}\left(2000 \mathrm{Ci} \times \mathrm{mmole}^{-1}\right)$ and ${ }^{14} \mathrm{C}-$ U-labelled aminoacids $\left(10 \mathrm{mCi} \times \mathrm{mmole}^{-1}\right)$ were obtained from New England Nuclear, USA. AH Sepharose-4B, Sephacryl S-300 and Blue Sepharose $\mathrm{CL}-6 \mathrm{~B}$ were obtained from Pharmacia, Sweden. Matrex Gel Red A was from Amicon, USA. Co(III)-ATP-o-phenanthroline was prepared as described in (23). ODS-Hypersil ( $5 \mu)$ was from Shandon, U.K. Radiation-sterilised plastic tubes were from Nunc, Denmark.

\subsection{Preparation of chlorophyllin-Sepharose}

Chlorophyllin was linked to the amino group of the six-carbon spacer of AH-Sepharose-4B in the following manner. Na-chlorophyllin $(270$ mg approx. $300 \mu$ moles) was dissolved in $200 \mathrm{ml}$ of water and the $\mathrm{pH}$ adjusted to 9.5 with $\mathrm{NaOH}$. AH-Sepharose $(7.5 \mathrm{~g})$ was swollen in $300 \mathrm{ml}$ of $0.5 \mathrm{M}-\mathrm{NaCl}$ and washed with $1500 \mathrm{ml}$ of 0.5 $\mathrm{M}-\mathrm{NaCl}$ followed by $1500 \mathrm{ml}$ distilled water. The chlorophyllin solution was mixed with the gel suspension. N-ethyl-N'-(diethylaminopropyl)carbodiimide hydrochloride $(57 \mathrm{mg}$ ) dissolved in $1 \mathrm{ml}$ of water was added. The $\mathrm{pH}$ dropped slowly and was adjusted to 8.0 during the first 15 minutes. The suspension was covered with aluminium foil and gently shaken for 2 days at 21 ${ }^{\circ} \mathrm{C}$. The gel was then filtered. In order to block any residual amino groups the gel was suspended in $10 \%$ acetic acid, $1 \mathrm{ml}$ of water containing 57 mg of carbodiimide was added and the suspension was shaken overnight. The chlorophyllinSepharose was washed with water. Non-covalently bound chlorophyllin was then removed by washing alternately with a solution of $0.5 \mathrm{M}$ $\mathrm{NaCl}$ containing $0.1 \mathrm{M}-\mathrm{Na}$-acetate ajusted to $\mathrm{pH}$ 4.5 with acetic acid and a solution of $0.5 \mathrm{M}$ $\mathrm{NaOH}$ containing $7 \mathrm{M}$-urea. The gel was stored in the acetate buffer and was equilibrated with the column elution medium prior to use.

\subsection{Plant material}

Ten to fifteen $\mathrm{kg}$ of barley seeds (Hordeum vitgare L., cv. Svalöfs Bonus) were germinated and grown on moist vermiculite contained in plastic trays in a dark room maintained at $23^{\circ} \mathrm{C}$ and 70 to $80 \%$ relative humidity. After six days of growth the seedlings were illuminated under Osram Fluora fluorescent lights at $2.59 \mathrm{~W} \times \mathrm{m}^{-2}$. Instead of a 6 hour illumination as in previous work $(15,21)$ a 12 hour greening period was used as this gave higher yields of protein and RNA. Leaves were harvested in portions, wrapped in aluminium foil and immediately cooled in ice.

\subsection{Isolation of plastids and stroma proteins}

The procedure was essentially as previously described (21). However the following improvements were made in the course of this work. One medium was used for plastid suspension, gel filtration and chromatography. This medium contained $0.3 \mathrm{M}$-glycerol, $0.1 \mathrm{M}$-Tricine- $\mathrm{NaOH}$ 
$\mathrm{pH}$ 9.0, $1 \mathrm{~mm}$-dithiothreitol and $25 \mathrm{mM}-\mathrm{MgCl}_{2}$. Plastids suspended in this medium were disrupted by passing through a French pressure cell and centrifuged at $300000 \mathrm{~g}$ for 25 minutes. The higher $\mathrm{Mg}^{2+}$ concentration and centrifugal force used in this study gave stroma protein preparations which were less contaminated by membranes and ribosomes compared to those previously obtained (21).

\subsection{Gel filtration and serial affinity chromatography of stroma proteins}

Gel filtration and serial affinity chromatography were carried out as previously described (21) using columns of Sephacryl S-300, Blue Sepharose, Matrex gel Red A and heme-Sepharose. In most of the experiments reported here a chlorophyllin-Sepharose column was used instead of heme-Sepharose. Chlorophyllin-Sepharose was easier to prepare than heme-Sepharose and was also more stable. The columns used had the following dimensions in $\mathrm{cm}$ : Sephacryl S-300 $5 \times 49$, Blue Sepharose $2.5 \times 12$, matrex gel Red A $2.5 \times 8$ and chlorophyllin-Sepharose $2.5 \times 12$. The present procedure also differed from the previous method (21) in that the Blue Sepharose bound protein was not further purified by passing through heme-Sepharose. The bound components were eluted from the affinity columns with $\mathrm{NaCl}(1 \mathrm{M})$ dissolved in the medium given in 2.4. Desalting by Sephadex G-50 and concentration of the components by pressure dialysis were performed as described in (21).

\subsection{Gel electrophoresis}

Non-denaturing polyacrylamide gel electrophoresis was carried out using the Tris-glycine system of DAvIS (4) either in tube gels or in slab gels. The tube gels were $0.6 \mathrm{~cm}$ in diameter and $10 \mathrm{~cm}$ in length. The slab gels were 30 by $20 \mathrm{~cm}$ and $2 \mathrm{~mm}$ thick. Stacking gels of $1 \mathrm{~cm}$ length for tube gels and $3 \mathrm{~cm}$ for slab gels were used. A current of $6 \mathrm{~mA}$ per tube or $60 \mathrm{~mA}$ per slab was used. Electrophoresis was carried out in a cold room at $4{ }^{\circ} \mathrm{C}$. For RNA purification and analysis of $5^{, 32} \mathrm{P}$ labelled RNAs, slabgels 16 by $46 \mathrm{~cm}$ and either $0.2 \mathrm{~mm}$ or $1 \mathrm{~mm}$ thick were prepared by polymerisation of a solution containing $8 \%$ acrylamide, $0.52 \%$ bis-acrylamide, $0.1 \mathrm{M}$-Trisborate, $2 \mathrm{mM}$-EDTA, and 7.5 M-urea. Acrylamide $(400 \mathrm{~g})$ and bis-acrylamide $(21 \mathrm{~g})$ were dissolved in water, made up to 1 litre and decolourised with active charcoal. A mixture of decolourised acrylamide stock $(200 \mathrm{ml})$, urea $(450 \mathrm{~g})$, water $(300 \mathrm{ml})$ was deionised with $10 \mathrm{~g}$ Amberlite MB 1 and added to $100 \mathrm{ml}$ of a Tris-borate-EDTA solution (1 M-Tris-borate and $20 \mathrm{~mm}$-EDTA). The volume was adjusted to 1 litre to give an acrylamide solution ready for polymerisation and was stored at $4{ }^{\circ} \mathrm{C}$ until required. Polymerisation was accomplished by adding to $100 \mathrm{ml}$ of this solution $25 \mu \mathrm{l}$ of $\mathrm{N}, \mathrm{N}, \mathrm{N}^{\prime}, \mathrm{N}^{\prime}$-tetramethylethylene diamine and then $170 \mu \mathrm{l}$ of $10 \%(\mathrm{w} / \mathrm{v})$ ammonium persulphate. No stacking gel was used. The RNA dissolved in a $7.5 \mathrm{M}$-urea solution containing a small amount of xylene cyanol and bromophenol blue, was applied to the top of the gel. Electrophoresis was carried out at $1000 \mathrm{~V}$ and at either room temperature or $60^{\circ} \mathrm{C}$ using a buffer containing $0.1 \mathrm{M}$-Tris-borate and $2 \mathrm{mM}$-EDTA. When the bromophenol blue had migrated about $36 \mathrm{~cm}$ from the origin, electrophoresis was terminated. RNA was eluted by soaking slices of gel in $300 \mathrm{~mm}-\mathrm{Na}$-acetate $\mathrm{pH} 5.5$ for 3 to 4 hours at $37^{\circ} \mathrm{C}$.

\subsection{High pressure liquid chromatography of RNA}

$\mathrm{C}_{18}$-linked to silica(ODS-Hypersil) was coated with trioctylmethyl-ammonium chloride and packed into columns as described in (2). An analytical column $300 \mathrm{~mm} \times 4.6 \mathrm{~mm}$ was packed using a Waters column packer and a preparative column $250 \mathrm{~mm} \times 9 \mathrm{~mm}$ was packed using a Magnus P6000 column packer (Magnus Scientific Instruments, Cheshire, England). Samples of RNA dissolved in water were injected into the columns (ca. $12 \mathrm{OD}_{260}$ units to analytical columns and 80 units to preparative columns) using an automatic injector module WISP $710 \mathrm{~B}$ and separated using a 4 hour linear gradient of $0.5 \mathrm{M}$-ammonium acetate $\mathrm{pH} 5.0$ to $2.3 \mathrm{M}$-ammonium acetate $\mathrm{pH} 5.1$ generated by two Waters pumps model $6000 \mathrm{~A}$ at a flow rate of $0.5 \mathrm{ml}$ per minute. One or one half $\mathrm{ml}$ fractions were collected in radiation sterilised plastic tubes 
using an LKB fraction collector. Ethanol (2.5 to 3 vol) was added and RNA allowed to precipitate either at $-20^{\circ} \mathrm{C}$ overnight or at $-80^{\circ} \mathrm{C}$ for 15 minutes. Precipitated RNA was collected by centrifugation for 30 minutes at $2500 \mathrm{~g}$ and dissolved in $100 \mu \mathrm{l}$ of distilled water.

\subsection{Isolation of RNA by phenol treatment and ethanol precipitation}

For this purpose analytical grade phenol was redistilled at $184^{\circ} \mathrm{C}$ and washed with a buffer at pH 9.0 containing $0.1 \mathrm{M}$-Tris- $\mathrm{HCl} 0.1 \mathrm{M}-\mathrm{NaCl}$ and $2 \mathrm{mM}$-EDTA until the phenol phase was alkaline. The material eluted from the chlorophyllin-Sepharose column, after concentration by pressure dialysis, was mixed with an equal volume of alkaline phenol. This mixture was shaken for 10 minutes at room temperature and centrifuged for 10 minutes at approximately $500 \mathrm{~g}$ in a bench top centrifuge. The lower phenol phase was discarded and the phenolisation procedure repeated. Phenol was removed from the aqueous phase by washing twice with chloroform:isoamyl alcohol $(24: 1, \mathrm{v} / \mathrm{v})$. One tenth vol of $3 \mathrm{M}-\mathrm{Na}$-acetate $\mathrm{pH} 5.5$ and $2.5 \mathrm{vol}$ of ethanol were added and the solution kept at $-18{ }^{\circ} \mathrm{C}$ overnight in order to precipitate the RNA. The RNA was collected by centrifugation at $9000 \mathrm{~g}$ for 10 minutes. RNA pellets were allowed to air dry at room temperature and dissolved in $500 \mu \mathrm{l}$ of distilled water. During these experiments it was found that the $\mathrm{NaCl}$-eluate from the chlorophyllin-Sepharose could be directly concentrated and phenolised without loss of RNA or its activity. The phenolisation procedure used for RNA isolation from enzyme incubation mixtures was slightly different in that $0.5 \mathrm{vol}$ of phenol and 0.5 vol of chloroform-isoamyl alcohol were added to the incubation mixture and shaken for 5 minutes. The mixture was then centrifuged in a microfuge. The upper aqueous layer was washed with chloroform-isoamyl alcohol and the RNA was precipitated as before.

The RNA isolations were carried out using sterile and RNAase-free glassware. In order to ensure RNAase-free conditions the glassware was soaked in $0.1 \mathrm{M}-\mathrm{NaOH}$ for one to two hours and then washed with glass-distilled water prior to sterilization.

\subsection{The reconstituted assay for} $\delta$-aminolevulinate synthesis

This assay was performed using L-glutamate$\mathrm{U}-{ }^{14} \mathrm{C}$ as substrate and combining the three fractions, chlorophyllin Sepharose bound, Blue Sepharose bound and the unbound fraction from the serial affinity chromatography. The incubation mixture contained in a total of $1 \mathrm{ml}$ $0.5 \mathrm{mM}$-ATP, $1 \mathrm{mM}-\mathrm{NADPH}, 5 \mathrm{~mm}$-levulinate, $2.5 \mu \mathrm{Ci}$ L-glutamate-U- ${ }^{14} \mathrm{C}, 25 \mathrm{mM}-\mathrm{MgCl}_{2}, 1$ to 2 $\mathrm{OD}_{260}$ units chlorophyllin-Sepharose bound fraction, 0.2 to $0.3 \mathrm{mg}$ Blue Sepharose bound protein, 0.3 to $0.5 \mathrm{mg}$ unbound protein, 0.3 M-glycerol, $0.1 \mathrm{M}$-Tricine- $\mathrm{NaOH} \mathrm{pH} 7.9$ and 1 mM-dithiothreitol. The incubations were carried out for 20 minutes at $28{ }^{\circ} \mathrm{C}$ and terminated by the addition of $100 \mu \mathrm{g}$ of $\delta$-aminolevulinate as carrier and $30 \mu \mathrm{l}$ of $70 \%$ perchloric acid. After centrifugation in a bench-top centrifuge the supernatant was analysed for ${ }^{14} \mathrm{C}$ incorporation into $\delta$-aminolevulinate. In some of the experiments the pellet was resuspended in $5 \%$ trichloracetic acid and the radioactivity in ${ }^{14} \mathrm{C}$-glutamylRNA determined as given in 2.10. Incorporation of label into $\delta$-aminolevulinate was measured as in $(5,15)$. This method involved purification by Dowex $50 \times 8$ ion exchange chromatography, conversion into the pyrrole with ethyl acetoacetate and final purification of the pyrrole by cellulose thin layer chromatography.

\subsection{Assay for glutamyl-RNA synthesis by determining the formation of trichloro- acetic acid insoluble radioactivity}

The incubation mixtures were either $1 \mathrm{ml}$ or $0.5 \mathrm{ml}$ and contained $0.5 \mathrm{mM}-\mathrm{ATP}, 25 \mathrm{~mm}$ $\mathrm{MgCl}_{2}, 1 \mathrm{~mm}$-dithiothreitol, ca. $50 \mu \mathrm{g}$ Blue Sepharose bound protein, $2.5 \mu \mathrm{Ci}$ L-glutamate$\mathrm{U}-{ }^{14} \mathrm{C}, 0.3 \mathrm{M}$-glycerol, $0.1 \mathrm{M}-\mathrm{Tricine}-\mathrm{NaOH} \mathrm{pH}$ 7.9 and 1 to $2 \mathrm{OD}_{260}$ units of RNA. Incubations were carried out for 20 minutes at $28^{\circ} \mathrm{C}$ and terminated by the addition of $100 \mu \mathrm{l}$ of $100 \%$ (w/v) trichloroacetic acid or $30 \mu \mathrm{l}$ of $70 \%$ perchloric acid. The precipitated material was collected on a paper disc and washed thoroughly with $5 \%$ trichloroacetic acid followed by $96 \%$ ethanol. The filter paper disc was then dried under an infra-red lamp and the radioactivity 
counted. Glutamate was replaced by other labelled amino acids for the determination of their binding to RNA.

\subsection{In vivo and in vitro incorporation of ${ }^{35} \mathrm{~S}$ - methionine into the components involved in $\delta$-aminolevulinate synthesis in greening barley leaves}

For the in vivo experiment approximately 60 $\mathrm{g}$ of leaves from six day old dark grown Bonus barley seedlings were allowed to green with their cut ends immersed in $8 \mathrm{ml}$ of water containing 2 $\mathrm{mCi}$ of ${ }^{35} \mathrm{~S}$-methionine. Plastids were isolated from these leaves and after disruption and centrifugation the stroma fraction was subjected to gel filtration and serial affinity chromatography as described in (21). For the in vitro incorporation experiment plastids were isolated from leaves of Bonus barley seedlings grown for six days in the dark and greened for 6 hours as described in (21). Isolated plastids were suspended in $0.3 \mathrm{M}$-glycerol, $0.1 \mathrm{M}$ - Tricine- $\mathrm{NaOH}$ pH $9.0,1 \mathrm{~mm}-\mathrm{MgCl}_{2}$ and $1 \mathrm{~mm}$-dithiothreitol. Fifty $\mathrm{ml}$ of plastid suspension containing 0.486 $\mathrm{mg}$ chlorophyll per $\mathrm{ml}$ were incubated for 20 minutes at $28^{\circ} \mathrm{C}$ with $5 \mathrm{mCi}$ of ${ }^{35} \mathrm{~S}$-methionine and $0.5 \mathrm{~mm}$-ATP in the light. After incubation the plastids were disrupted by passing through a French pressure cell at 8000 psi, centrifuged and the supernatant analysed by gel filtration on Sephacryl S-300 and serial affinity chromatography as described in (21).

\subsection{Labelling the 5 ' end of RNA with ${ }^{32} \mathbf{P}$}

In order to ensure the presence of a free $5^{\prime} \mathrm{OH}$ on the RNA it was incubated with alkaline phosphatase prior to labelling. RNA (ca. 1.5 $\mathrm{OD}_{260}$ units) was incubated in a total volume of $100 \mu$ l containing 60 units of alkaline phosphatase, $0.3 \mathrm{M}$-glycerol, $0.1 \mathrm{M}$-Tricine- $\mathrm{NaOH} \mathrm{pH}$ 9.0, $25 \mathrm{mM}-\mathrm{MgCl}_{2}$ and $1 \mathrm{~mm}$-dithiothreitol. The mixture was incubated for 30 minutes at $37^{\circ} \mathrm{C}$ and RNA was extracted by phenolisation and ethanol precipitation. The RNA was then incubated in a total volume of $100 \mu \mathrm{l}$ containing 28 units of polynucleotide kinase, $0.2 \mathrm{mCi}$ of ATP $\left(\gamma-{ }^{32} \mathrm{P}\right), 50 \mathrm{~mm}$-Tris- $\mathrm{HCl} \mathrm{pH} 7.5,10 \mathrm{~mm}-\mathrm{MgCl}_{2}$ and 5 mM-dithiothreitol. After a 30 minute incubation at $37{ }^{\circ} \mathrm{C}$, the labelled RNA was extracted by phenolization and ethanol precipitation.

\subsection{Hybridisation of ${ }^{32} \mathbf{P}-5$ '-RNA to recombinant DNA molecules containing barley chloroplast sequences}

The library of recombinant DNA molecules containing barley chloroplast sequences prepared and characterised in (20) was used for hybridisation. The preparation of this library involved isolation and purification of chloroplasts, extraction of DNA, restriction endonuclease digestion of DNA, insertion of DNA fragments into plasmids pBR322 and pBR325 and cloning in E. coli. Clones of E. coli carrying recombinant plasmids covering $80 \%$ of the genome were available. One of these clones, pHvC35 was extensively subcloned into the M13 bacteriophage strains mp8 and mp9 (used for sequencing) according to the procedure in (19). One microgram of plasmid DNA (1) or 0.1 $\mu \mathrm{g}$ of 'phage DNA was spotted onto a nitrocellulose paper (Millipore $A B$ ). The paper was then soaked successively in a solution of $0.1 \mathrm{M}$ $\mathrm{NaOH}$ containing $1.5 \mathrm{M}-\mathrm{NaCl}$ and a solution of $0.5 \mathrm{M}$-tris- $\mathrm{HCl}$ pH 7.5 containing $3 \mathrm{M}-\mathrm{NaCl}(5$ minutes in each solution). The paper was airdried and then baked at $80^{\circ} \mathrm{C}$ for 1 to 2 hours. This paper with adsorbed DNA was then soaked in $1 \mathrm{ml} / \mathrm{cm}^{-2}$ of $50 \%(\mathrm{v} / \mathrm{v})$ formamide, $0.3 \mathrm{M}$ $\mathrm{NaCl}, 30$ mM-Na-acetate pH 7.0, 0.2\% (w/v) bovine serum albumin (Sigma fraction $\mathrm{V}$ ), $0.2 \%$ (w/v) polyvinylpyrrolidone (m.w. 40000 ), $0.2 \%$ (w/v) polyethylene glycol 4000 and $100 \mu \mathrm{g} \times \mathrm{ml}^{-1}$ salmon sperm DNA (sonicated and heat denatured) at $37^{\circ} \mathrm{G}$ with shaking. After 2 to 4 hours the solution was replaced with the hybridisation solution $\left(0.2 \mathrm{ml} \times \mathrm{cm}^{-2}\right.$ of paper). Hybridisation solution was prepared by adding $5 \times 10^{6} \mathrm{cpm}$ of 5 , ${ }^{32} \mathrm{P}$ labelled $\delta$-ALA-RNA (RNA involved in $\delta$-aminolevulinate synthesis) to the above solution. After overnight hybridisation at $37^{\circ} \mathrm{C}$ the paper was washed twice with a solution containing $0.3 \mathrm{M}-\mathrm{NaCl}, 30 \mathrm{mM}-\mathrm{Na}$-citrate and $0.1 \%$ $(\mathrm{w} / \mathrm{v})$ sodium dodecyl sulphate and twice in a solution containing $15 \mathrm{~mm}-\mathrm{NaCl}, 1.5 \mathrm{mM}-\mathrm{Na}-$ citrate and $0.1 \%$ sodium dodecyl sulphate. The paper was vigorously shaken in 200 to $300 \mathrm{ml}$ of 
the solutions for 15 minutes at $60^{\circ} \mathrm{C}$. The papers were air dried and autoradiographed overnight using Kodak Royal X-Omat RP film.

\subsection{Assays for adenylate kinase, ADP-ATP exchange and ADP hydrolysis}

Reaction mixture for adenylate kinase contained in $1 \mathrm{ml} 0.5 \mathrm{~mm}$-ADP, $2.5 \mu \mathrm{Ci}{ }^{14} \mathrm{C}$-ADP, $0.6 \mathrm{mg}$ Blue Sepharose bound protein, $10 \mathrm{~mm}$ methionine sulphoximine, $0.3 \mathrm{M}$-glycerol, 0.1 M-Tricine- $\mathrm{NaOH} \mathrm{pH} \mathrm{8.0,} 25 \mathrm{mM}-\mathrm{MgCl}_{2}$ and 1 mM-dithiothreitol. After incubation for 20 minutes at $28^{\circ} \mathrm{C}, 5 \mathrm{mg}$ each of ATP, ADP and AMP were added followed by $25 \mu$ of $70 \%$ perchloric acid. The precipitated protein was removed by centrifugation. Nucleoside phosphates were then separated by polyethylenimine cellulose column chromatography and analysed for radioactivity. For ADP-ATP exchange the above reaction mixture was modified by including $0.1 \mathrm{mM}-\mathrm{ATP}$ and changing the ADP concentration to $0.1 \mathrm{mM}$. Phosphatase activity could be estimated in both these assays by the amount of ${ }^{14} \mathrm{C}$-AMP formed.

2.15. Separation of ATP, ADP and AMP by polyethylenimine (PEI) cellulose column chromatography

A column of PEI cellulose $(1.5 \times 5 \mathrm{~cm})$ was packed and washed with a solution of $2 \mathrm{mM}-\mathrm{LiCl}$ containing $0.08 \%$ formic acid. The mixture of ATP, ADP and AMP was loaded on to the column and washed with the above solution until AMP was eluted. Then a linear gradient from $70 \mathrm{ml}$ of the above solution to $70 \mathrm{ml}$ of $2 \mathrm{M}-\mathrm{LiCl}$ containing $7.6 \%$ formic acid was applied to the column, resulting in the elution of ADP followed by ATP.

\subsection{Other methods}

Protein concentrations were determined by the microbiuret procedure according to (12). Amino acid compositions were determined using a Durrum D-580 Amino acid Analyser after acid hydrolysis for 24 hours at $110^{\circ} \mathrm{C}$. Radioactivity was determined by scintillation counting. RNA is expressed in $\mathrm{OD}_{260}$ units where 1 unit gives an optical density of 1 at $260 \mathrm{~nm}$ when dissolved in $1 \mathrm{ml}$ of water and measured using a cuvette of $1 \mathrm{~cm}$ light path.

\section{RESULTS}

3.1. Properties of the chlorophyllin-Sepharose bound component

Chlorophyllin inhibited $\delta$-aminolevulinate synthesis giving $50 \%$ inhibition at $30 \mu \mathrm{M}$. Using chlorophyllin-Sepharose instead of heme-Sepharose in the serial affinity procedure, a fraction binding to this matrix was isolated. This fraction stimulated $\boldsymbol{\delta}$-aminolevulinate synthesis when combined with the Blue Sepharose bound and unbound fractions. The absorption spec-

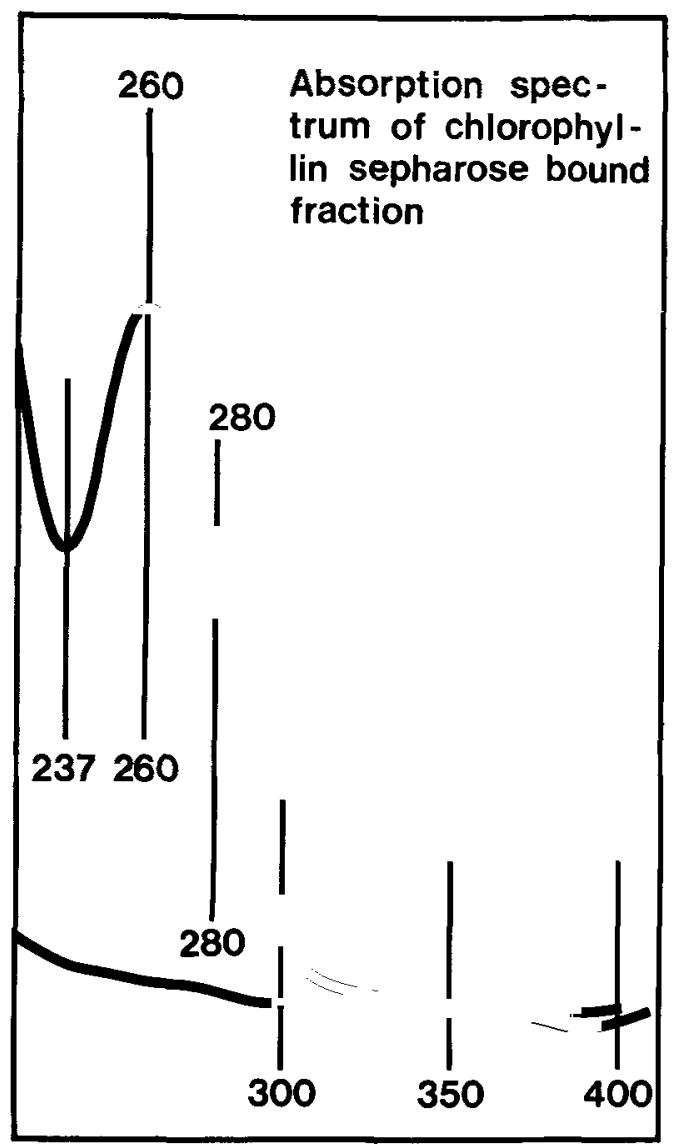

Figure 1. Absorption spectrum of chlorophyllin-Sepharose bound fraction required for $\delta$-aminolevulinate synthesis. (Lower curve is baseline obtained without sample.) 


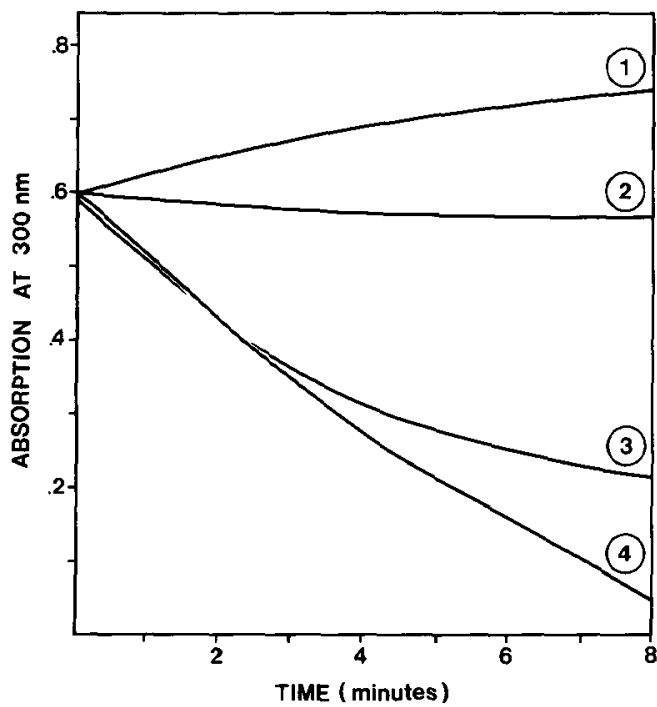

Figure 2. The effect of ribonuclease on the chlorophyllin-Sepharose bound fraction and on the RNA extracted from this fraction.

Assays were in $0.1 \mathrm{M}$-Na-acetate buffer $\mathrm{pH} 5.0$ at room temperature $\left(21^{\circ} \mathrm{C}\right.$ ). A mixture of RNAase $\mathrm{A}$ ( 5 $\mu \mathrm{g})$ and $T_{1}(1 \mu \mathrm{g})$ was added and the change in the absorbance of light at $300 \mathrm{~nm}$ with time was recorded. Curve 1. Chlorophyllin-Sepharose bound fraction added. Curve 2. Control, no additions. Curve 3. RNA extracted from the chlorophyllin-Sepharose bound fraction and added to the reaction. Curve 4. Soluble yeast RNA added.

trum of the chlorophyllin-Sepharose bound fraction (Figure 1) revealed a maximum at 260 $\mathrm{nm}$ and a $260 / 280$ ratio of 1.7 characteristic of nucleic acids. The fraction binding to the chlorophyllin-Sepharose did not serve as a sub- strate for a mixture of RNAase $A$ and $T_{1}$ when tested in a spectroscopic assay according to (18). The substances with absorption maxima at 260 $\mathrm{nm}$ in this fraction were extracted by phenol treatment and ethanol precipitation. After this treatment the $300 \mathrm{~nm}$ absorption decreased on incubation with the mixture of RNAase A and $T_{1}$ (Figure 2, curve 3). It is therefore concluded that the chlorophyllin-Sepharose fraction contains RNA. The chlorophyllin-Sepharose bound material catalysed phosphate exchange between ATP and ADP (tested as described in 2.14). This activity was lost after phenol treatment and ethanol precipitation.

\subsection{Characterisation of the chlorophyllin- Sepharose bound component required for $\delta$-aminolevulinate synthesis \\ 3.2.1. Formation of glutamyl-RNA and its correlation to $\delta$-aminolevulinate synthesis}

Incubation of the chlorophyllin-Sepharose bound fraction with L-glutamate- $\mathrm{U}-{ }^{14} \mathrm{C}$ and the Blue Sepharose bound fraction in the presence of ATP and $\mathrm{Mg}^{2+}$ produced trichloroacetic acid insoluble radioactivity. Four different nucleoside phosphates ATP, ADP, GTP, and CTP were tested for their ability to stimulate $\delta$-aminolevulinate synthesis and to stimulate glutamate binding to the chlorophyllin-Sepharose bound fraction. All four nucleoside phosphates tested were stimulatory (Table I). ATP was most effective followed by ADP, GTP and CTP in decreasing order. When the chlorophyllin-Sepharose

Table I.

Nucleoside phosphate specificity for $\delta$-aminolevulinate synthesis and glutamate binding to the chlorophyllin-Sepharose bound fraction. The chlorophyllin-Sepharose bound fraction equivalent to $2.08 \mathrm{OD}_{260}$ units was used in the assays. $\delta$-Aminolevulinate synthesis and trichloroacetic acid (TCA) insoluble radioactivity were determined in separate assays as given in 2.9 and 2.10 .

Nucleoside phosphate Conversion of L-glutamate- $\mathrm{U} \cdot{ }^{14} \mathrm{C}$ into: added $(0.5 \mathrm{mM})$

\begin{tabular}{cc}
\hline$\delta$-aminolevulinate (cpm) & TCA insoluble radioactivity $(\mathrm{cpm})$ \\
\hline 3860 & 850 \\
2349700 & 57300 \\
1980600 & 54050 \\
226000 & 12130 \\
28900 & 1720 \\
\hline
\end{tabular}




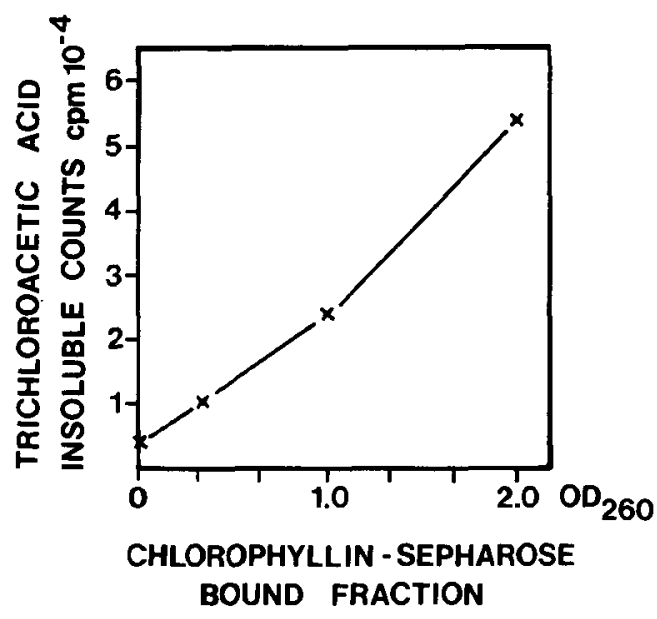

Figure 3. The effect of increasing the chlorophyllin-Sepharose bound fraction on the formation of glutamylRNA. All assays contained $1.3 \mathrm{mg}$ of Blue Sepharose bound fraction.

bound fraction was heated to $100{ }^{\circ} \mathrm{C}$ for five minutes and cooled in ice it lost the ability to reconstitute $\delta$-aminolevulinate synthesis as well as the capacity to bind glutamate.

Increasing amounts of glutamate were converted into material insoluble in trichloroacetic acid by adding increasing amounts of chlorophyllin-Sepharose bound material (Figure 3). However, in assays containing equal amounts of chlorophyllin-Sepharose material, maximal amounts of trichloroacetic acid insoluble radio-

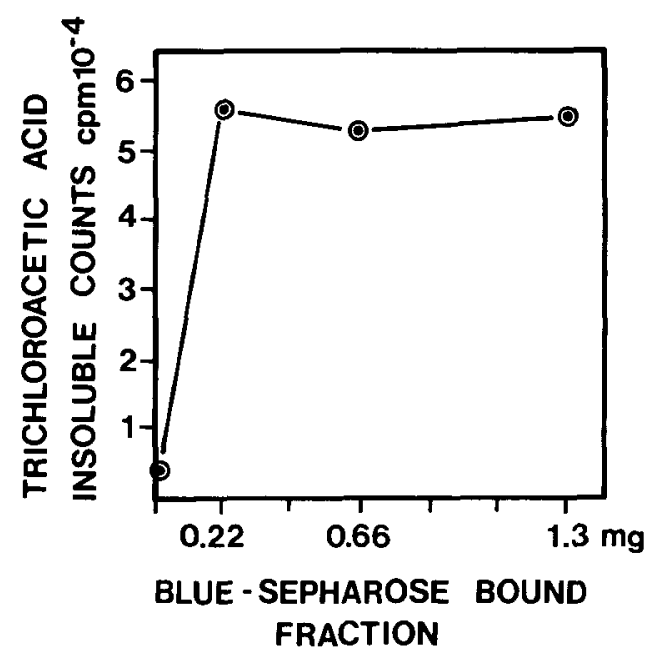

Figure 4. The effect of increasing the Blue Sepharose bound fraction on glutamyl-RNA formation. All assays contained $2.0 \mathrm{OD}_{260}$ units of chlorophyllin-Sepharose bound fraction.

activity were reached at the lowest tested level of the Blue Sepharose bound fraction (Figure 4). It was concluded that an enzyme present in the Blue Sepharose bound fraction catalyses binding of glutamate.

Addition of pancreatic ribonuclease $A$ or snake venom phosphodiesterase to the enzyme assay strongly inhibited $\delta$-aminolevulinate synthesis and the formation of trichloroacetic acid insoluble radioactivity (Table II). The addition

\section{Table II.}

The effect of nucleases on $\delta$-aminolevulinate synthesis and binding of glutamate- $U-{ }^{14} \mathrm{C}$ to the chlorophyllin-Sepharose bound material. The amounts of nucleases added to assays are: snake venom phosphodiesterase $\mathrm{I} .0 .08$ units; spleen phosphodiesterase II, 0.5 units; ribonuclease $A, 2 \mu \mathrm{g}$; ribonuclease $\mathrm{T}_{1}, 1 \mu \mathrm{g}$; deoxyribonuclease I, $1 \mu \mathrm{g}$. $\delta$-aminolevulinate syntheses and trichloroacetic acid insoluble counts formation were carried out in separate assays as given in 2.9 and 2.10 . n.t $=$ not tested

Nuclease added

Conversion of L-glutamate- $U-{ }^{14} \mathrm{C}$ into:

$\delta$-aminolevulinate
$(\mathrm{cpm}, \%$ of control)

(cpm, \% of control)

1. None (control)

2. Snake venom phosphodiesterase I

3. Spleen phosphodiesterase II

4. Pancreatic ribonuclease $A$

5. Ribonuclease $T_{1}$

6. Deoxyribonuclease I
100

2

90

0.6

87

94

\section{0}

0.7

78

1

n.t

n.t 
Table III.

Aminoacylation of different amino acids with the chlorophyllin-Sepharose bound material. The assays were carried out in a total volume of $1 \mathrm{ml}$ containing $1.1 \mathrm{OD}_{260}$ units of chlorophyllin-Sepharose bound fraction, $40 \mu \mathrm{g}$ of of Blue Sepharose bound protein, $0.025 \mu$ moles $\left(0.25 \mu \mathrm{Ci},{ }^{14} \mathrm{C}\right)$ of amino acid, with and without $0.5 \mathrm{mM}-\mathrm{ATP}$.

\begin{tabular}{lc}
\hline Amino acid & $\begin{array}{c}\text { ATP dependent, trichloroacetic acid } \\
\text { insoluble radioactivity. cpm }\end{array}$ \\
\hline 1. Alanine & 378 \\
2. Arginine & 784 \\
3. Aspartic acid & 101 \\
4. Glutamic acid & 1271 \\
5. Glycine & 546 \\
6. Histidine & 186 \\
7. Isoleucine & 360 \\
8. Leucine & 1001 \\
9. Lysine & 416 \\
10. Phenylalanine & 889 \\
11. Proline & 308 \\
12. Serine & 158 \\
13. Threonine & 303 \\
14. Tyrosine & 231 \\
15. Valine & 335 \\
\hline
\end{tabular}

of spleen phosphodiesterase, ribonuclease $T_{1}$ or deoxyribonuclease gave only a slight inhibition of $\delta$-aminolevulinate synthesis. The spleen phosphodiesterase specifically hydrolyses phosphodiester bonds of RNAs from the 5'end giving free 3' nucleotides whereas the snake venom enzyme hydrolyses RNAs from the 3' end and produces free 5 ' nucleotides. The strong inhibition of both $\delta$-aminolevulinate synthesis and formation of trichloroacetic acid insoluble counts by the snake venom enzyme suggests that glutamate binds to an RNA at the 3' end and that $\delta$-aminolevulinate synthesis proceeds via this glutamyl-RNA.

\subsubsection{Presence of $t R N A$ in the chlorophyllin- Sepharose bound fraction}

The chlorophyllin-Sepharose bound material was tested for its ability to accept 15 different amino acids catalysed by enzymes present in the Blue epharose bound fraction. Table III illustrates that arginine, glutamate, glycine, leucine and phenylalanine were bound in significant amounts while the other amino acids were bound in trace amounts. It was thus concluded that the chlorophyllin-Sepharose bound fraction contains several tRNAs.

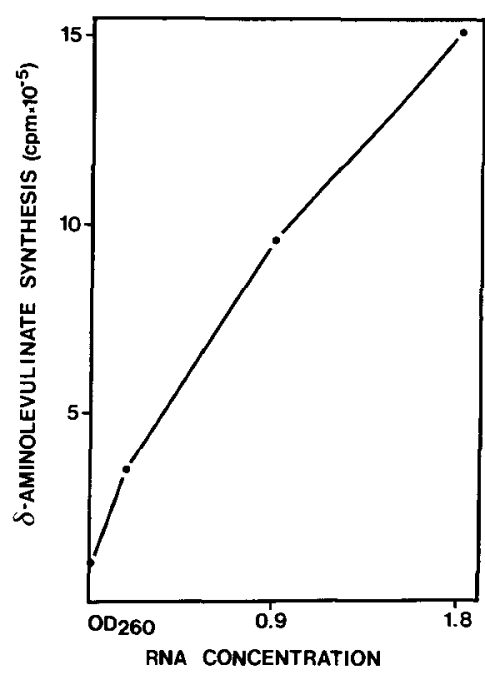

Figure 5. The effect of increasing amounts of RNA on $\delta$-aminolevulinate synthesis.

The RNA extracted from the chlorophyllin-Sepharose bound fraction was added to a $1 \mathrm{ml}$ reaction mixture containing $0.21 \mathrm{mg}$ of Blue Sepharose bound protein, $0.3 \mathrm{mg}$ of unbound protein, $0.5 \mathrm{~mm}-\mathrm{ATP}, 1$ mM-NADPH, 5 mM-levulinate, $25 \mathrm{~mm}-\mathrm{MgCl}_{2}, 1 \mathrm{~mm}$ dithiothreitol, $0.3 \mathrm{M}$-glycerol and $0.1 \mathrm{M}$-Tricine- $\mathrm{NaOH}$ pH 7.9. 


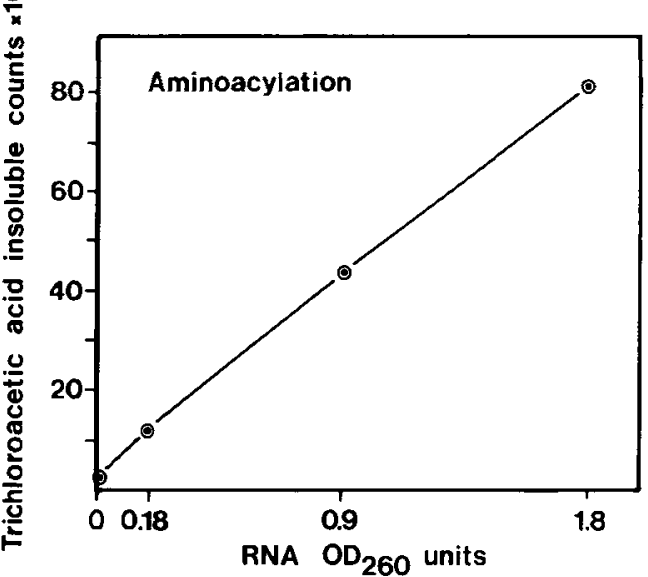

Figure 6. The effect of increasing the RNA on glutamyl-RNA formation. The RNA obtained by phenolisation and ethanol precipitation of the chlorophyllinSepharose bound fraction was used. All assays contained $50 \mu \mathrm{g}$ of Blue Sepharose bound protein.

\subsubsection{Glutamyl-RNA formation and reconstitution of $\delta$-aminolevulinate synthesis with RNA isolated from the chlorophyllin-Sepharose bound fraction}

The RNA present in the chlorophyllin-Sepharose bound fraction was isolated by phenolisation and ethanol precipitation. As judged from the $260 \mathrm{~nm}$ light absorption the RNA was completely recovered by this procedure. This RNA reconstituted $\delta$-aminolevulinate synthesis when combined with the Blue Sepharose bound and the unbound fraction. Proportionally increasing amounts of $\delta$-aminolevulinate were synthesised by adding increasing amounts of RNA (Figure 5). Incubation of the RNA with the Blue Sepharose bound fraction, ATP, $\mathrm{Mg}^{2+}$ and L-gentomate- $\mathrm{U}-{ }^{14} \mathrm{C}$ resulted in the formation of trichloroacetic acid insoluble radioactivity. The acid insoluble counts increased proportionally to the amount of RNA added (Figure 6). The chlorophyllin-Sepharose bound fraction, as well as the RNA obtained from this fraction, accepted 40 to 90 pmoles of glutamate per $\mathrm{OD}_{260}$ unit depending on the preparation. Using RNA isolated from the chlorophyllin-Sepharose bound fraction, $a \mathrm{~K}_{\mathrm{m}}$ for glutamate of $1 \mu \mathrm{M}$ was measured.

\subsubsection{Identification of glutamyl-RNA as an intermediate in $\delta$-aminolevulinate synthesis}

The RNA (12.3 OD $_{260}$ units) extracted from the chlorophyllin-Sepharose bound fraction was incubated in an assay slightly modified to that given in 2.10 . High specific activity, ${ }^{3} \mathrm{H}$-glutamate $\left(3 \times 10^{7} \mathrm{cpm}\right)$ and 4 -fold more Blue Sepharose bound protein $(200 \mathrm{mg})$ were used. After incubation RNA was recovered by phenol treatment and ethanol precipitation as given in 2.8 . The presence of $1.54 \times 10^{6} \mathrm{cpm}$ in the re-extracted RNA indicated that glutamate covalently binds to the RNA. Incubation of this glutamyl-RNA $\left(1.1 \times 10^{6} \mathrm{cpm}\right)$ in the absence of ATP and in the reconstituted enzyme assay resulted in the formation of radioactive $\delta$-aminolevulinate $\left(26 \times 10^{3} \mathrm{cpm}\right)$. It was thus concluded that glutamyl-RNA is an intermediate in the conversion of glutamate to $\delta$-aminolevulinate. The low yield ( $2 \%)$ is possibly due to the instability of the glutamyl-RNA.

\subsubsection{Protein contamination in the $R N A$ isolated from the chlorophyllin-Sepharose bound fraction}

Amino acid analysis of the RNA prepared by phenolisation and ethanol precipitation of the chlorophyllin-Sepharose bound material revealed the following amino acids (molar ratios given in parenthesis): aspartate (4.51), threonine (1.41), serine (0.74), glutamate (4.41), proline $(0.3)$, alanine (3.60), cysteine (3.39), valine (5.94), methionine $(0.43)$, isoleucine $(0.38)$, leucine $(0.54)$ and lysine $(0.60)$. There was a large ninhydrin positive peak in the position of glycine. This originated from adenine in the RNA since ATP subjected to the same analysis gave a peak in the same position.

\subsection{Effect of digestion of the RNA with $S$. aureus protease, alkaline phosphatase and phosphodiesterase II on glutamyl-RNA formation and the reconstitution of $\delta$-aminolevulinate synthesis}

The RNA was incubated in a suitable buffer at the optimal pHs for the enzymes. For each assay a control incubation in the same buffer 
Table IV.

The effect of pre-incubation of the RNA with several enzymes on reconstitution of $\delta$-aminolevulinate synthesis and glutamyl-RNA formation. The enzyme concentrations and the buffers used are: $S$. aureus protease 0.2 units, 0.1 M-Na-acetate pH 4.0 or 0.1 M-Tricine-NaOH pH 7.9: alkaline phosphatase 20 units, 0.1 M-Tricine-NaOH pH 9.0: spleen phosphodiesterase II 0.1 units, Na-acetate pH 6.5. The preincubations were carried out for 1 hour at $37^{\circ} \mathrm{C}$ and terminated by phenolisation and ethanol precipitation of the RNA. This RNA was used for reconstitution of $\delta$-aminolevulinate synthesis and glutamyl-RNA formation in separate assays as given in 2.9 and 2.10 .

\begin{tabular}{lcc}
\hline Pre-incubation with & \multicolumn{2}{c}{ Conversion of L-glutamate-U- ${ }^{14} \mathrm{C}$ into: } \\
\cline { 2 - 3 } & $\delta$-aminolevulinate & glutamyl-RNA \\
(cpm, \% of control)
\end{tabular}

without the enzyme was carried out. The RNA was then recovered from the incubation mixture by phenolisation and ethanol precipitation and tested for its ability to reconstitute $\delta$-aminolevulinate synthesis and to bind to glutamate (Table IV). Fifteen per cent inhibition of $\delta$-aminolevulinate synthesis and $10 \%$ inhibition of glutamyl-RNA formation were induced by preincubating the RNA with $S$. aureus protease at $\mathrm{pH}$ 4.0. Preincubation with this enzyme at pH 7.9 had no effect on glutamyl-RNA formatíon but stimulated $\delta$-aminolevulinate synthesis by $17 \%$. Alkaline phosphatase pretreatment caused a $62 \%$ inhibition of the glutamate acceptor activity and a $22 \%$ stimulation of $\delta$-aminolevulinate synthesis. This indicated the presence of glutamate acceptor RNAs other than the one involved in $\delta$-aminolevulinate synthesis and which are sensitive to alkaline phosphatase treatment. The ability of the RNA to reconstitute $\delta$-aminolevulinate synthesis as well as its ability to accept glutamate were destroyed by preincubating with spleen phosphodiesterase II at $\mathrm{pH}$ 6.5. This is in contrast to addition of this enzyme directly to the reconstituted assay containing the chlorophyllin-Sepharose bound material (cf. Table II). It is concluded that the RNA involved in $\delta$-aminolevulinate synthesis becomes more sensitive to spleen exonuclease attack after phenol extraction and ethanol precipitation.

3.4. The specificity of the RNA involved in $\delta$-aminolevulinate synthesis

The RNA isolated from the chlorophyllin-Sepharose bound fraction could not be replaced

Table V.

Specificity of $\delta$-ALA-RNA. The incubation mixture contained in $1 \mathrm{ml} 0.21 \mathrm{mg}$ Blue Sepharose bound protein, 0.3 mg unbound protein. The amounts of RNA added to this mixture in OD $_{260}$ units are: $\delta$-ALA-RNA 0.03, tRNA ${ }^{\text {Gin }}$ from E. coli 0.2 and tRNA from wheat germ 6.8. The conversion of glutamate to $\delta$-aminolevulinate and glutamyl-RNA formation in the same assay was determined as given in 2.9 and 2.10 .

\begin{tabular}{|c|c|c|}
\hline \multirow{3}{*}{ Assay } & \multicolumn{2}{|c|}{ Conversion of L-glutamate- $\mathrm{U}-{ }^{14} \mathrm{C}$ into: } \\
\hline & $\delta$-aminolevulinate & glutamyl-RNA \\
\hline & & \\
\hline \multicolumn{3}{|l|}{ 1. Blue Sepharose bound } \\
\hline + unbound fraction & 100 & 100 \\
\hline 2. $1+\delta$-ALA-RNA & 778 & 507 \\
\hline 3. $1+\operatorname{tRNA}^{\text {Glu }}$ from E. coli & 87 & 5489 \\
\hline 4. $1+t R N A$ from wheat germ & 42 & 715 \\
\hline
\end{tabular}




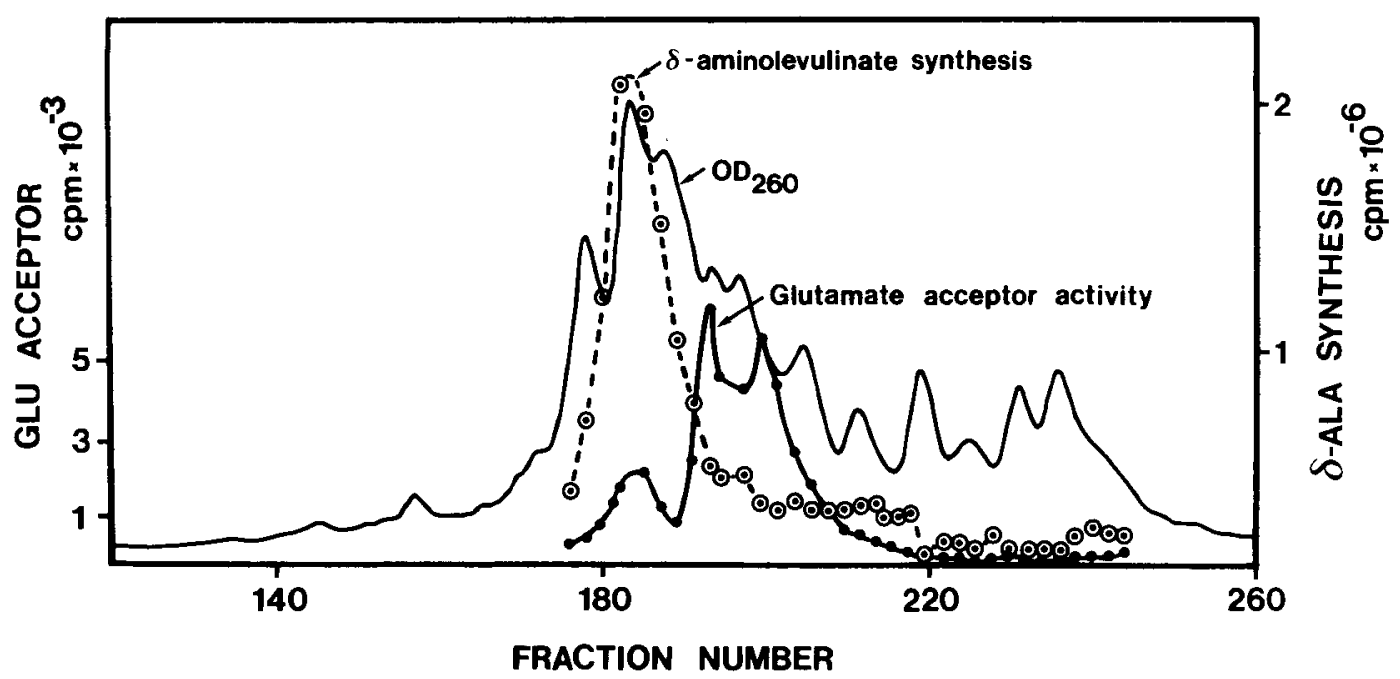

Figure 7. Purification of $\delta$-ALA-RNA by high pressure liquid chromatography. An analytical column was used. Assays were as given in 2.9 and 2.10. Glutamate (GLU) binding to RNA and $\delta$-aminolevulinate (ALA) synthesis were determined in the same assay.

by tRNA ${ }^{\text {Glu }}$ from E. coli or wheat germ tRNA in the reconstituted assay for $\delta$-aminolevulinate synthesis (Table V). However these transfer RNAs accepted glutamate efficiently during the incubation of the reconstituted assay mixture.

\subsection{Purification of the RNA involved in $\delta$-aminolevulinate synthesis ( $\delta$-ALA- RNA) by High Pressure Liquid Chromatography}

The RNA obtained from the chlorophyllinSepharose bound material was fractionated on an analytical column of $\mathrm{C}_{18}$ Hypersil containing trioctylmethyl ammonium chloride. Fifteen to sixteen peaks of ultraviolet light absorbtion were observed in the column eluate (Figure 7). The RNA in $0.5 \mathrm{ml}$ fractions of the column eluate was precipitated with ethanol at $-18{ }^{\circ} \mathrm{C}$ overnight. After dissolving the RNA in $100 \mu$ l of distilled water it was tested for glutamate acceptor activity and for the ability to reconstitute $\delta$-aminolevulinate synthesis. There were three peaks of glutamate acceptor activity. One of these eluted at the same position at the highest $260 \mathrm{~nm}$ light absorbing peak and the compounds of these fractions reconstituted $\delta$-aminolevulinate synthesis. Trailing this peak were two other glutamate acceptor RNA peaks and the RNA in these fractions did not reconstitute

Table VI.

The effect of heme, Mg-protoporphyrin IX and Co(III)-ATP-o-phenanthroline on glutamyl-RNA formation. 8-ALA-RNA purified by HPLC was used in the assays.

Assay

Glutamyl-RNA formation

Trichloroacetic acid insoluble radioactivity

(cpm, \% of control)

\begin{tabular}{lr}
\hline 1. Control & 100 \\
2. Co(III)-ATP-o-phenanthroline $(1 \mathrm{mM})$ & 38 \\
3. Heme $(50 \mu \mathrm{M})$ & 84 \\
4. Mg-protoporphyrin IX $(50 \mu \mathrm{M})$ & 92
\end{tabular}


$\delta$-aminolevulinate synthesis. When the preparative column was used the first peak of glutamate acceptor activity and the peak for $\delta$-aminolevulinate reconstitution did not coincide with the highest $260 \mathrm{~nm}$ light absorbing peak. The two activity peaks eluted together approximately 60 seconds later than the highest $260 \mathrm{~nm}$ light absorbing peak. Fractions from the preparative column eluate were also analysed for phenylalanine, serine, arginine and leucine acceptor activities. It was found that the phenylalanine and leucine acceptor activities were well separated from the RNA peak involved in $\delta$-aminolevulinate synthesis. However, the first glutamate acceptor activity peak overlapped partially with the serine and entirely with the arginine acceptor activity peaks. The observations from HPLC analysis show that there is an RNA molecule specifically involved in $\delta$-aminolevulinate synthesis in greening barley. This RNA is referred to as $\delta$-ALA-RNA. The $\delta$-ALA-RNA is similar to tRNA ${ }^{\text {Glu }}$ in that it can accept glutamate.

\subsection{The effect of heme, $\mathrm{Mg}$-protoporphyrin IX} and Co(III)-ATP-o-phenanthroline on the activity binding glutamate to $\delta$-ALA-RNA

In previous work these compounds were found to strongly inhibit $\delta$-aminolevulinate synthesis $(7,16)$ and they were therefore tested using the RNA in the first glutamate acceptor peak eluted from the HPLC (Table VI). Co(III)-ATP. o-phenanthroline tested at $1 \mathrm{mM}$ gave a $62 \%$ inhibition of glutamate binding to the RNA. $\delta$-ALA-RNA purified by HPLC and subjected to electrophoresis in a non-denaturing gel could be visualised by staining with $\mathrm{Co}$ (III)-ATP-ophenanthroline. Heme and $\mathrm{Mg}$-protoporphyrin tested at $50 \mu \mathrm{M}$ caused respectively $16 \%$ and $8 \%$ inhibition. The two metalloporphyrins at this concentration inhibit $\delta$-aminolevulinate synthesis by respectively $95 \%$ and $60 \%(7)$.

Figure 8. Purification of $\delta$-ALA-RNA by urea-polyacrylamide gel electrophoresis. $\mathrm{Xc}=\mathrm{xylene}$ cyanol, $\mathrm{Bpb}$ $=$ Bromophenol blue.

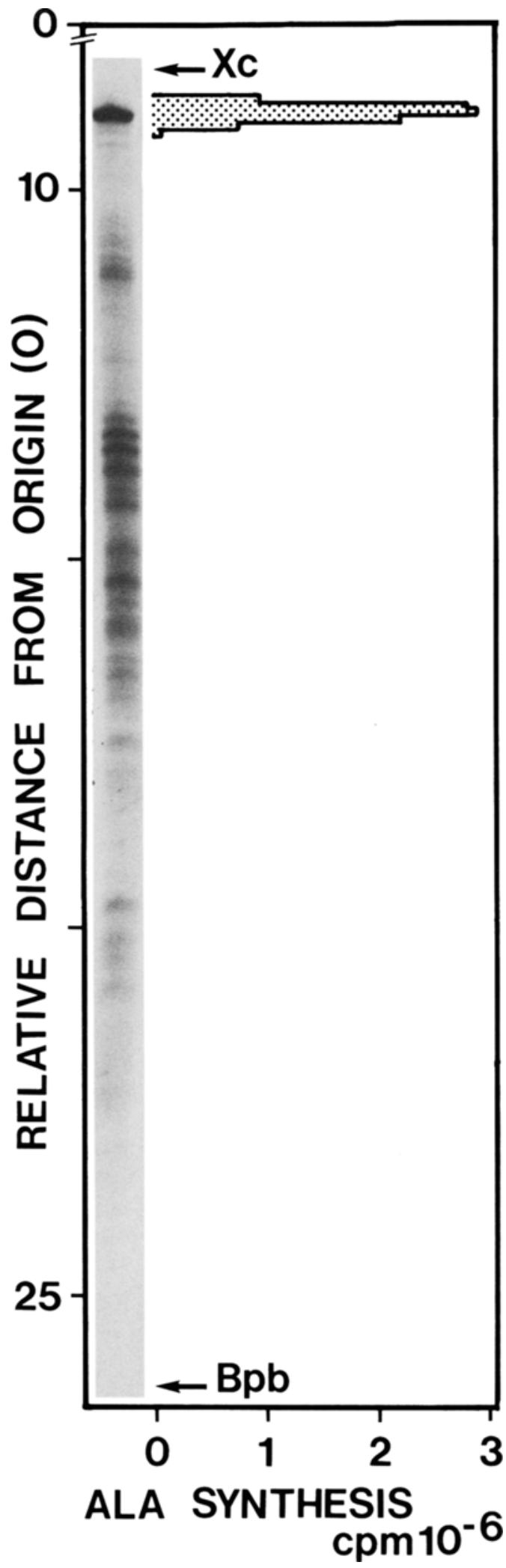




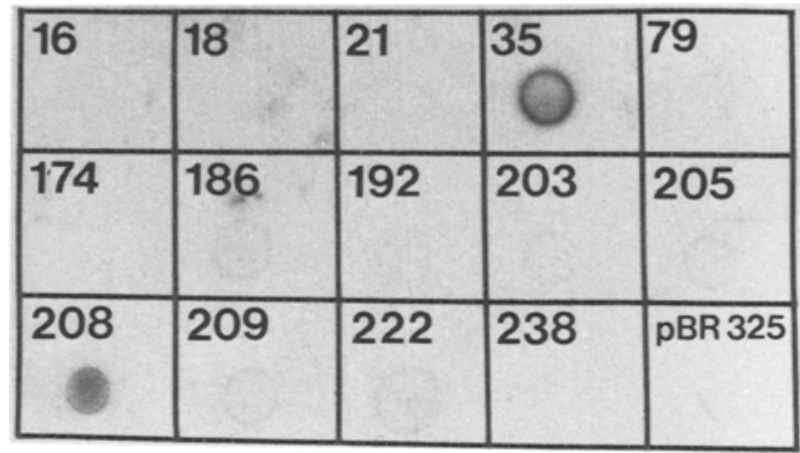

Figure 9. Hybridisation of $\delta$-ALA-RNA plasmids pHvC35 and pHvC208 carrying a common $3.9 \mathrm{~kb}$ fragment of the barley chloroplast DNA. Numbers refer to the recombinant plasmids ( $\mathrm{pHvC}$ ) characterised in (20) and covering $80 \%$ of the chloroplast genome as presented in Figure 11.

\subsection{Further purification of $\delta$-ALA-RNA by} urea-polyacrylamide gel electrophoresis

The RNA from the HPLC fractions which reconstituted $\delta$-aminolevulinate synthesis was precipitated with ethanol. It was then enzymatically labelled at the 5 ' end with ${ }^{32} \mathrm{P}$ and analysed by electrophoresis in nondenaturing polyacrylamide gels. This resolved ca. 30 labelled bands in the size range of 20 to 70 bases. One of these was more prominently labelled than the others and migrated slightly faster than the xylene cyanol tracking dye. Electrophoresis at room temperature $\left(22^{\circ} \mathrm{C}\right)$ did not change the banding pattern. The HPLC purified $\delta$-ALA-RNA, mixed with some $5,{ }^{32} \mathrm{P}-\delta$-ALA-RNA was separated at room temperature by electrophoresis in a $1 \mathrm{~mm}$ thick $8 \%$ polyacrylamide gel containing $7.5 \mathrm{M}$-urea. After electrophoresis, the gel was sliced into 140 transverse strips (each ca. $3.3 \mathrm{~mm}$ wide) and from each strip RNA was extracted and precipitated with ethanol. The prominently labelled band migrating a few $\mathrm{cm}$ in front of the xylene cyanol marker (towards the anode) was the only RNA able to reconstitute $\delta$-aminolevulinate synthesis when combined with the Blue Sepharose bound and the unbound fractions (Figure 8). Amino acid analysis of the $\delta$-ALA-RNA preparation obtained after urea gel electrophoresis gave three peaks corresponding to serine, histidine and glycine.
The peak at the position of histidine could arise from contaminating Tris and the large peak corresponding to glycine could be derived from adenine. The apparent absence of amino acids apart from serine $\left(0.15\right.$ nmoles $\times \mathrm{OD}_{260}$ unit $\left.^{-1}\right)$, indicated that the $\delta$-ALA-RNA obtained after electrophoresis is free of protein.

3.8. Hybridization of $\delta$-ALA-RNA to a $3.9 \mathrm{~kb}$ fragment of the barley chloroplast genome The two $\delta$-ALA-RNA preparations, one obtained after the high pressure liquid chromatography purification step and the other after gel electrophoresis were labelled enzymatically with ${ }^{32} \mathrm{P}$ at the 5' end and tested for their ability to hybridize with cloned fragments of barley chloroplast genome covering $81 \%$ of the plastid genome. Six recombinant plasmids carrying inserts from a Hind III digest of plastid DNA (pHvC 16, 18, 21, 35, 79 and 174) and 8 with inserts from a Pst I digest ( $\mathrm{pHvC} 186,192,203$, $205,208,209,222$ and 238) were applied to a grid pattern on a nitrocellulose filter and hybridised to the labelled $\delta$-ALA-RNA. Nitrocellulose filters containing the hybrids were washed under conditions ( $T_{m}-8$, for DNA/DNA hybridisations, assuming $40 \% \mathrm{GC}$ content) in which only highly matched hybrids are stable. The $\delta$-ALA-RNA was only retained on $\mathrm{pHvC} 35$ and pHvC208 (Figure 9). A common $3.9 \mathrm{~kb}$ sequence present in the $4.3 \mathrm{~kb}$ insert in $\mathrm{pHvC} 35$ and in the $20.4 \mathrm{~kb}$ insert in $\mathrm{pHvC208}$, was thus identified as the site of hybridisation of $\delta$-ALARNA.

The $4.3 \mathrm{~kb}$ insert in pHvC35 was isolated and fragmented using the restriction enzymes Sal I, Pst I, Hpa II, Rsa I, Xba I, Taq I, Eco RI, Bam HI, Hind III and Sau 3A. The DNA fragments from these digests were inserted into the replicative form DNA of M13 phages and E. coli cells were transformed. The recombinant 'phages were isolated after propagation and characterised by sequencing. With the help of overlapping and complementary sequences, the positions of the M13 inserts in the $4.3 \mathrm{~kb}$ Hind III fragment from barley chloroplast DNA were identified. These characterised 'phages were applied to a nitrocellulose filter and hybridised 
with ${ }^{32} \mathrm{P}-\delta$-ALA-RNA. Nine M13 clones produced stable hybrids with $\delta$-ALA-RNA (Figure 1.0). Of these, 5 clones are derived from one strand of the chloroplast DNA and 4 from the complementary strand. One clone (A7) which hybridised to $\delta$-ALA-RNA contained 2 to $3 \mathrm{~kb}$ of unidentified DNA resulting from ligation of more than one DNA fragment into the M13 vector. This analysis showed that the RNA hybridized with one site in each DNA strand (Figure 10). The two sites were separated by ca. 400 nucleotides. The two $\delta$-ALA-RNA preparations behaved identically in both hybridisations.
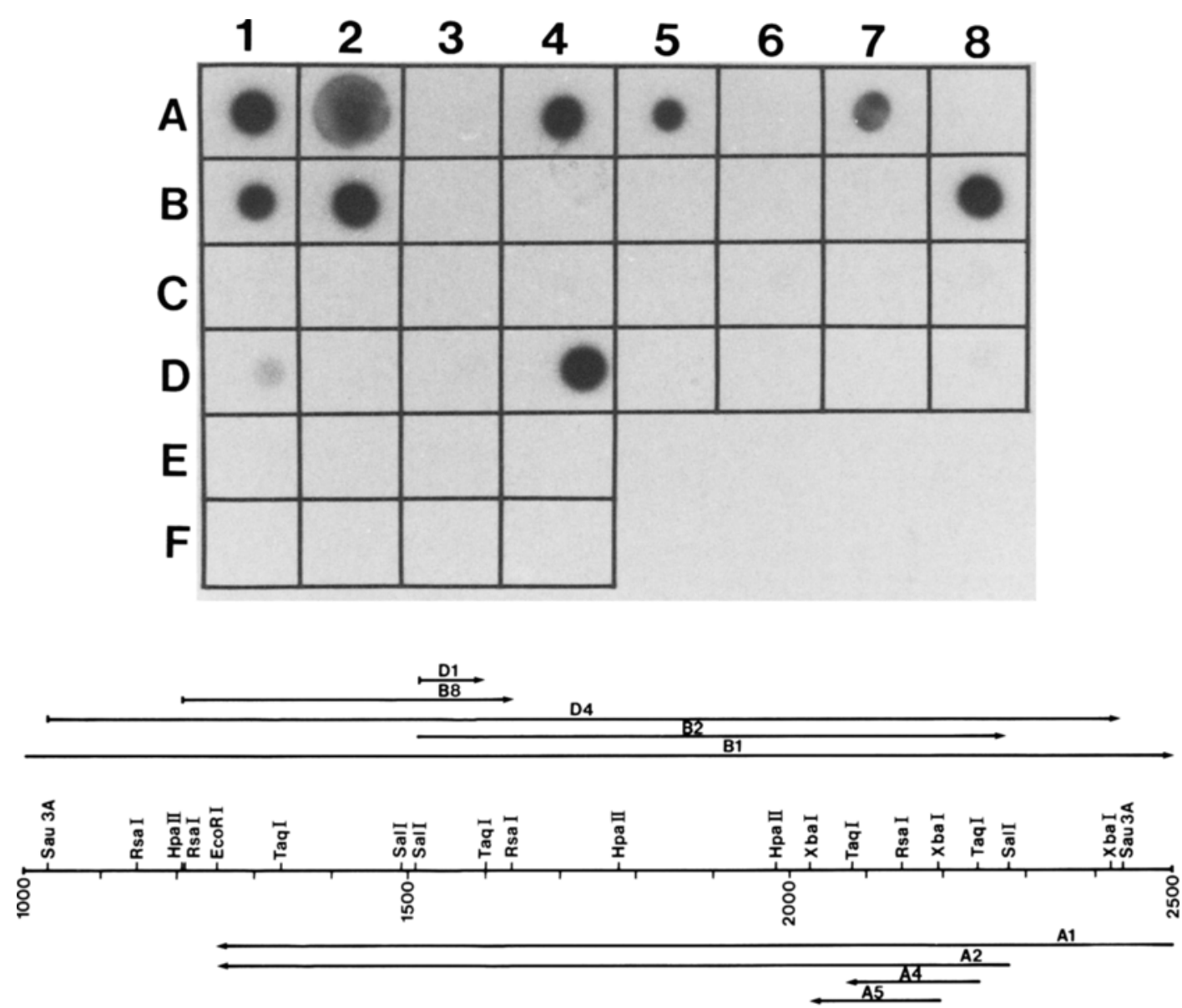

Figure 10. Hybridisation of $\delta$-ALA-RNA to $9 \mathrm{M} 13$ phages each carrying a subfragment from one of the DNA strands of the $4.3 \mathrm{~kb}$ Hind $11 \mathrm{ll}$ fragment. a. 19 different M1 3 clones were tested. The sequence of the first 200-300 nucleotide of the inserts were determined and located in the total sequence of the Hind III fragment (19). The clones in rows $A, C$ and $E$ contained inserts from one DNA strand of the Hind III fragment and clones in rows B, D and F contained DNA from the other strand. The clone in $A 7$ contained 2 to $3 \mathrm{~kb}$ of unidentified DNA resulting from ligation of more than one restriction fragment into the $M 13$ vector. $b$. Map of part of the $4.3 \mathrm{~kb}$ Hind III restriction fragment of barley chloroplast DNA. The nucleotide at the end of the Hind III site nearest to the inverted repeat is designated as 1 and the inserts in the M13 clones hybridising to $\delta$-ALA-RNA in the grid pattern (except for clone A7) are mapped in the barley chloroplast DNA. 


\subsection{Other enzymic activities observed in the Blue Sepharose bound fraction}

The three fractions from the serial affinity chromatography, the chlorophyllin-Sepharose bound, the Blue Sepharose bound and the unbound had to be combined and the cofactors ATP, NADPH and $\mathrm{Mg}^{2+}$ had to be included in the assay in order to synthesise $\delta$-aminolevulinate from glutamate. Glutamate 1-semialdehyde aminotransferase (E.C.5.4.3.8) was the active component in the unbound fraction (21) and $\delta$-ALA-RNA was the active component in the chlorophyllin-Sepharose bound fraction. For identification of the components present in the Blue Sepharose bound fraction and involved in $\delta$-aminolevulinate synthesis we analysed this fraction for several ATP, NADPH and NADH utilising enzymes.

In addition to the aminoacyl synthetase activities the Blue Sepharose bound fraction contained the ability to hydrolyse ADP, and an ability to synthesise ATP from ADP. These enzymic activities were not affected by the addition of glutamate. The Blue Sepharose bound fraction was analysed by electrophoresis in a non-denaturing slab gel and tested for diaphorase activity. The gel was incubated for 15 minutes at $30^{\circ} \mathrm{C}$ in a solution of $1 \%$ triphenyltetrazolium chloride containg either $1 \mathrm{mM}$ NADPH or 1 mM-NADH. Six bands of NADPH dependent and one band of NADHdependent diaphorase activity were observed in the gel. The NADH-dependent diaphorase band did not correspond to any of the NADPH dependent diaphorase bands.

\subsection{Incorporation of ${ }^{35} \mathrm{~S}$-methionine into the components of the $\delta$-aminolevulinate synthesising system of greening barley leaves}

In a previous study we observed prominent

${ }^{35} \mathrm{~S}$-methionine incorporation into a polypeptide in the plastid stroma during the initial 6 hours of greening of dark-grown barley leaves (15). This polypeptide co-purified with glutamate 1-semialdehyde aminotransferase during gel filtration and DEAE-Sephadex chromatography. Since then we have developed methods for extensive purification of two components involved in $\boldsymbol{\delta}$-aminolevulinate synthesis in barley,
8-ALA-RNA and the aminotransferase with an $M_{r}$ of 80,000 (16). Experiments were carried out to determine whether the prominently labelled polypeptide observed during greening of barley is a component involved in $\delta$-aminolevulinate synthesis and moreover whether it is made outside or inside the plastids.

When ${ }^{35} \mathrm{~S}$-methionine was incorporated into greening seedling leaves and analysed as given in 2.11 , the following specific activities were observed in the fractions containing the components of the $\delta$-aminolevulinate synthesising system: the unbound fraction, $336000 \mathrm{cpm} \times \mathrm{mg}$ protein $^{-1}$, Blue Sepharose bound fraction, $199000 \mathrm{cpm} \times \mathrm{mg}$ protein $^{-1}$, and the heme-Sepharose bound fraction, $377000 \mathrm{cpm} \times \mathrm{OD}_{260}$ unit". The specific activity of the heme-Sepharose bound fraction is expressed per $\mathrm{OD}_{260}$ unit because the major component in this fraction is RNA. Electrophoresis in the Tris-glycine system of DAVIS (4) and autoradiography of the gel revealed 45 labelled bands in the unbound, 21 in the Blue Sepharose bound and 6 in the heme-Sepharose bound fractions. The most heavily labelled band in the unbound fraction migrated in the position corresponding to glutamate 1-semialdehyde aminotransferase. The heme bound fraction had a labelled band migrating with the bromophenol blue marker. This band stained with $\mathrm{Co}$ (III)-ATP-o-phenanthroline complex. When ${ }^{35} \mathrm{~S}$-methionine was incorporated into isolated plastids in the light and fractionated by serial affinity chromatography the following specific activities were observed in the fractions analysed: the unbound fraction, $112000 \mathrm{cpm} \times \mathrm{mg}$ protein ${ }^{-1}$, the Blue Sepharose bound fraction, $84000 \mathrm{cpm} \times \mathrm{mg}$ pro$\operatorname{tein}^{-1}$, and the heme-Sepharose bound fraction, $9000 \mathrm{cpm}$ per $260 \mathrm{~nm}$ OD unit. After electrophoresis in a non-denaturing gel the heme bound fraction had a single faintly labelled band migrating with bromphenol blue. This band stained with $\mathrm{Co}$ (III)-ATP-o-phenanthroline complex. In the unbound fraction 18 labelled bands were observed but none corresponded to glutamate 1-semialdehyde aminotransferase.

\subsection{Electrophoretic mobility of the heme- Sepharose bound component}

The heme-Sepharose bound fraction was sub- 
Table VII.

The electrophoretic isolation of the component required for $\delta$-aminolevulinate synthesis in the heme Sepharose bound fraction. Glutamate 1-semialdehyde aminotransferase $(0.6 \mathrm{mg})$ purified according to (16) was used. The material eluted from the heme-Sepharose column was subjected to non-denaturing gel electrophoresis (2.6) and the fraction co-migrating with bromophenol blue (3.11) was tested.

\begin{tabular}{lc}
\hline Assay & $\begin{array}{l}\text { Conversion of L-glutamate- } \mathrm{U}^{14} \mathrm{C} \\
\text { into } \delta \text {-aminolevulinate, cpm }\end{array}$ \\
\hline $\begin{array}{l}\text { 1. Blue Sepharose bound + purified } \\
\text { glutamate l-semialdehyde aminotransferase }\end{array}$ & 5100 \\
$\begin{array}{l}\text { 2. } 1+\text { heme-Sepharose bound component } \\
\text { (isolated by electrophoresis) }\end{array}$ & 555500 \\
\hline
\end{tabular}

jected to electrophoresis in a non-denaturing tube gel with a dialysis bag tied at the end of the gel tube. Immediately after the bromophenol dye marker had migrated out of the bag electrophoresis was discontinued. The contents of the dialysis bag gave a 11 -fold stimulation of $\delta$-aminolevulinate synthesis when added to an assay containing Blue Sepharose bound protein and purified glutamate 1-semialdehyde aminotransferase (Table VII). The absorption spectrum of the material collected in the dialysis bag by electrophoresis had a single absorption maximum at $263 \mathrm{~nm}$ with a $260 / 280$ ratio of 1.5 indicating the presence of nucleic acid. This material contained protein as determined by microbiuret and amino acid analysis. It is concluded that heme-Sepharose binds $\delta$-ALARNA.

\section{DISCUSSION}

In previous investigations we established that in greening barley $\delta$-aminolevulinate is synthesised from glutamate by plastid stroma-located enzymes utilising the cofactors ATP, NADPH and $\mathrm{Mg}^{2+}(5,6,13)$. It was postulated that this synthesis involves an ATP-dependent activation of the carboxyl group of glutamic acid adjacent to the amino group followed by an NADPHdependent reduction to give glutamate 1 -semialdehyde $(14,17)$. The activation was thought to be catalysed by a kinase giving glutamate 1 phosphate. In the present investigation an RNA involved in the ATP dependent activation of glutamate was isolated from the plastid stroma of greening barley leaves. This RNA, referred to as $\delta$-ALA-RNA, reconstituted $\delta$-aminolevulinate synthesis when combined with the Blue Sepharose bound and the unbound fractions. The identification of a glutamyl-RNA as an intermediate preceding glutamate 1 -semialdehyde supports the previously postulated idea of activation of the $\mathrm{C} 1$ followed by its reduction to aldehyde. However the idea that glutamate 1-phosphate is the immediate precursor of glutamate-semialdehyde is excluded.

The evidence for the participation of an RNA in the conversion of glutamate to $\delta$-aminolevulinate is as follows: $\delta$-aminolevulinate synthesis in vitro was strongly inhibited by the addition of RNAase A or snake venom phosphodiesterase; $\delta$-aminolevulinate synthesis was reconstituted by a highly purified RNA preparation containing no detectable protein; glutamate bound to this RNA in the presence of ATP, $\mathrm{Mg}^{2+}$ and a ligase and was converted into $\delta$-aminolevulinate. The conversion of glutamylRNA to $\delta$-aminolevulinate required NADPH together with the Blue Sepharose bound fraction and the unbound fraction (containing glutamate 1-semialdehyde aminotransferase). ATP was not required.

Snake venom phosphodiesterase strongly inhibited binding of glutamate to $\delta$-ALA-RNA. This enzyme specifically hydrolyses phosphodiester bonds from the 3 ' end of RNA molecules giving free 5 ' nucleotides. Therefore it is concluded that glutamate binds to the 3' end of $\delta$-ALA-RNA. In all known tRNAs and viral RNAs containing amino acid acceptor activity, the amino acid binds to an adenine of a -CCA sequence at the 3' end (9). The $\delta$-ALA-RNA 


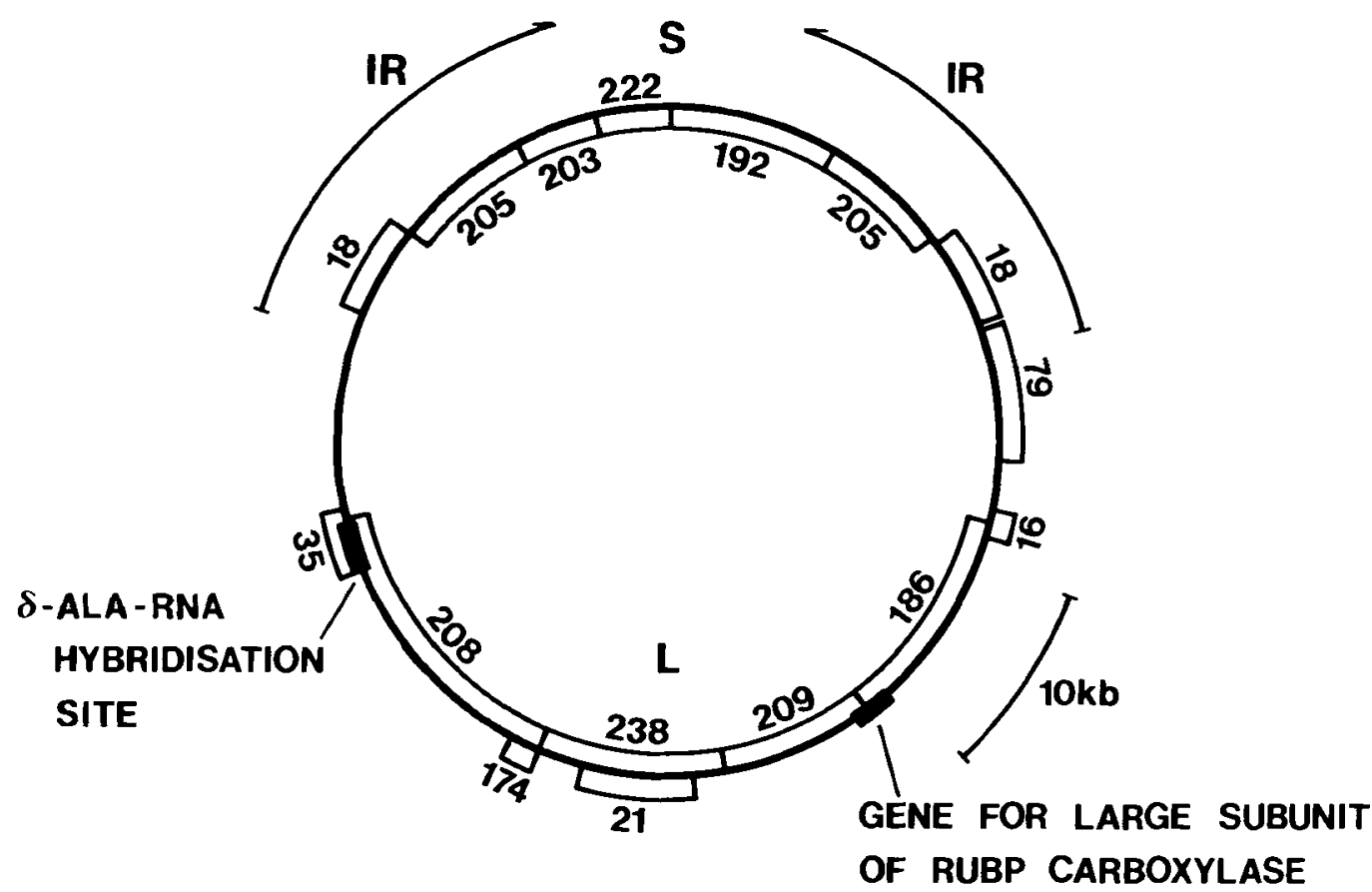

Figure 11. A map of barley chloroplast genome showing the $\delta$-ALA-RNA hybridisation site. The locations of the recombinant plasmids tested for hybridisation with $\delta$-ALA-RNA are also given. The landmarks in this map are derived from (19). $\mathrm{S}=$ small single copy region containing $14 \mathrm{~kb}$. $\mathrm{L}=$ large-single copy region containing $78 \mathrm{~kb}$. Two inverted repeats (IR) containing $21 \mathrm{~kb}$ each.

could also have a CCA sequence at the 3' end.

The purification of $\delta$-ALA-RNA to near homogeneity is reported in this paper. The $\delta$-ALA-RNA hybridised to a $3.9 \mathrm{~kb}$ fragment of chloroplast DNA. As illustrated in the Figure 11 this fragment is located in the large single copy region of the plastid genome ca. $38 \mathrm{~kb}$ from the gene for ribulose bisphosphate carboxylase large subunit and ca. $12 \mathrm{~kb}$ from one of the inverted repeats. Northern blotting analysis has shown that this region hybridises to 14 different sized RNAs (ranging between 0.3 and $6 \mathrm{~kb}$ ), four of which are light induced transcripts (19, 20). By analysing M13 clones carrying single stranded regions of the insert in $\mathrm{pHvC} 35$ it was shown that $\delta$-ALA-RNA hybridised to two subregions, one in each of the two DNA strands. Sequencing of $\delta$-ALA-RNA is currently in progress and will provide the information necessary for locating the gene of $\delta$-ALA-RNA.

${ }^{35} \mathrm{~S}$-Methionine is incorporated into glutamate 1-semialdehyde aminotransferase when the label was administered to greening barley leaves. Incubation of isolated plastids with ${ }^{35} \mathrm{~S}$ methionine gave no incorporation into this protein. Therefore we suggest that glutamate 1 -semialdehyde aminotransferase is synthesised in the cytosol and transported into the chloroplast. Since it was one of the heavily labelled bands observed in the electrophoretic pattern it is also considered as one of the major products synthesised in the barley leaves during greening. Hybridisation of $\delta$-ALA-RNA to chloroplast DNA on the other hand indicates its transcription and charging inside the chloroplast. Analysis of products synthesised in isolated barley plastids using ${ }^{35} \mathrm{~S}$-methionine gave a radioactive band in the position of $\delta$-ALA-RNA. Since amino acid analysis showed that a methionine containing peptide comigrated with $\delta$-ALARNA during electrophoresis in the non-denaturing gel system used, it is very likely that the label was incorporated into this comigrating peptide. However, incorporation of ${ }^{35} \mathrm{~S}$ into a 
sulphur-containing nucleotide, in the $\delta$-ALARNA cannot be ruled out.

$\mathrm{Co}$ (III)-ATP-o-phenanthroline is a strong inhibitor of both $\delta$-aminolevulinate synthesis and binding of glutamate to $\delta$-ALA-RNA. By staining with this complex the position of $\delta$-ALARNA in non-denaturing gels was located. The inhibitor must therefore bind to $\delta$-ALA-RNA. Since $\mathrm{Co}(\mathrm{III})-\mathrm{ATP}$-o-phenanthroline inhibits several ATP dependent enzymes by occupying the ATP binding site of these enzymes (23) we suggest that the ATP binding site involved in the ligase reaction is located on the $\delta$-ALA-RNA and the RNA is part of the enzyme. This is in contrast to tRNA aminoacylations, where the aminoacyl synthetases contain the ATP binding site, but may be comparable to the enzyme ribonuclease $P$, which cleaves precursor $t R N A s$ to give mature $t R N A$ s with correct 5 ' sequences. In this enzyme the catalytic activity resides in the RNA moiety of this enzyme. This was shown by isolating the RNA moiety free of protein and demonstrating its ability to process precursor tRNAs (8).

ATP is the only nucleoside phosphate that stimulates tRNA aminoacylation. Nucleoside phosphate-dependent dependent binding of glutamate to $\delta$-ALA-RNA was observed with ATP, GTP, CTP and ADP. The stimulation of ADP is probably indirect via ATP because of the presence of adenylate kinase in the ligase containing Blue Sepharose bound fraction used in the assay. Purification of the ligase will determine whether GTP and CTP directly stimulate glutamate binding to $\delta$-ALA-RNA. The Blue Sepharose bound fraction catalysed the binding of 15 different amino acids to the chlorophyllinSepharose bound fraction. It also catalysed glutamate binding to wheat germ and E. coli tRNA. The Blue Sepharose bound proteins must therefore include many different aminoacyl synthetases. In addition, the Blue Sepharose bound fraction catalyses hydrolysis of ADP, as well as the oxidation of NADH and NADPH (diaphorase activity). The enzymes participating in the conversion of glutamate to $\delta$-aminolevulinate and present in this fraction have to be purified and characterised to determine if any of the above activities are additionally involved in $\delta$-aminolevulinate synthesis.
The $\delta$-ALA-RNA is associated with an acidic peptide in the chlorophyllin-Sepharose bound fraction. The presence of this protein protected the $\delta$-ALA-RNA from complete digestion by RNAase $A$ and $T_{1}$ (Figure 2). We think that $\delta$-ALA-RNA is also protected from degradation during gel filtration and serial affinity chromatography procedure by the same protein. Whether the association is to be considered as contamination or has some functional significance has to be elucidated.

The enzyme catalysing the binding of glutamate to $\delta$-ALA-RNA is tentatively called a ligase. The stability of glutamyl- $\delta$ ALA-RNA during phenolisation and ethanol precipitation indicate that glutamate binds covalently to $\delta$ ALA-RNA probably by an aminoacyl bond. The low $\mathrm{K}_{\mathrm{m}}$ for glutamate in this reaction is comparable to the $\mathrm{K}_{\mathrm{m}}$ for amino acids in tRNAaminoacyl synthetase reactions, indicating a high affinity of the enzyme for its substrate.

Previously we established that the Blue Sepharose bound fraction together with the heme-Sepharose bound fraction ( $\delta$-ALA-RNA containing fraction) catalysed the conversion of glutamate to glutamate 1-semialdehyde in the presence of ATP, NADPH and $\mathrm{Mg}^{2+}$ as cofactors (21). From this and the observations presented in this paper we conclude that the Blue Sepharose bound fraction contains two separate enzyme activities involved in $\delta$-aminolevulinate synthesis. One of these activities catalyses the binding of glutamate to $\delta$-ALA-RNA in the presence of ATP and $\mathrm{Mg}^{2+}$ and is partially characterised in this paper. The NADPH requirement for glutamate 1-semialdehyde synthesis suggests that the Blue Sepharose bound fraction includes another enzyme, an NADPHdependent dehydrogenase catalysing the reduction of activated glutamate to the semialdehyde. This dehydrogenase should have a site recognising $\delta$-ALA-RNA as it was not possible to reconstitute $\delta$-aminolevulinate synthesis using glutamate acceptor RNAs from E. coli or wheat germ. Heme and Mg-protoporphyrin in low concentrations $(50 \mu \mathrm{M})$ strongly inhibit $\delta$-aminolevulinate synthesis in vitro (7). GlutamylRNA formation with $\delta$-ALA-RNA purified by HPLC is not significantly inhibited by these metalloporphyrins at these concentrations. 
Therefore it is likely that another activity, such as the NADPH dependent dehydrogenase involved in $\delta$-aminolevulinate synthesis is inhibited by heme and Mg-protoporphyrin. Purification of the ligase and the dehydrogenase is necessary to determine whether glutamyl- $\delta$ ALA-RNA and glutamate 1-semialdehyde are the only two intermediates in the conversion of glutamate to $\delta$-aminolevulinate. However, it is difficult to see how dioxovalerate could be involved as an intermediate in the light of the above observations.

The final step in the $\delta$-aminolevulinate biosynthetic pathway is catalysed by the enzyme glutamate 1-semialdehyde aminotransferase (E.C.5.4.3.8). This step has been elucidated in previous work by characterising (14) and purifying the enzyme (16) and by establishing the structure of the glutamate 1-semialdehyde intermediate by mass and nuclear magnetic spectroscopy of the synthetic acetal derivative (11).

Aminoacylated-RNAs play a role in peptide bond formation in protein synthesis but in bacteria they are also known to be important in other biosynthetic processes such as cell wall biosynthesis (3). In this paper an unusual role for glutamyl-RNA in chlorophyll synthesis is demonstrated. If this glutamyl-RNA is also involved in thylakoid membrane protein synthesis we may begin to understand how the plant coordinates synthesis of chlorophyll and chlorophyll-binding proteins during chloroplast development.

\section{ACKNOWLEDGEMENTS}

We wish to thank Dr. ANDERS BRANDT for teaching us some of the RNA techniques, Professor,DITER VON WETTSTEIN and DT. DAVID SIMPSON for critically reading the manuscript, Dr. C. POulsen for providing the pHvC plasmids, Mrs. BODIL CORNELIUSSEN for amino acid analysis, Mrs. NINA RAMUSSEN for drawing the figures and Mrs. ANN-SOFI STEINHOLTZ for photography. This research was supported in part by research contract No. GB 1-4-024DK of the Biomolecular engineering programme of the Commision of the European Community to professor D. VON WETTSTEIN and in part by an EMBO fellowship ALTF 69-1982 to R.P. OLIVER.

\section{REFERENCES}

1. Birnboim. C. \& J. Doly: A rapid alkaline extraction procedure for screening recombinant plasmid DNA. Nucl. Acids Res. 7, 1513-1520 (1979)

2. Bischoff, R.E., E. Graeser \& L. MCLaughlin: tRNA separation by high performance liquid chromatography using a aggregate of ODS-Hypersil and trioctymethyl ammonium chloride. J. Chromatog. 257, 305-315 (1983)

3. Chatterjee, S.N. \& J.T. Park: Biosynthesis of cell wall mucopeptide by a particulate fraction from Staphyloccocus aureus. Proc. Natl. Acad. Sci. 51, 9-16 (1964)

4. Davis B.J: Disc electrophoresis II. Method and application to human serum proteins. Annals New York Acad. Sciences. 121, 404-427 (1964)

5. Gough, S.P. \& C.G. Kannangara: Synthesis of $\delta$-aminolevulinate by isolated plastids. Carlsberg Res. Commun. 41, 184-190 (1976)

6. Gough, S.P. \& C.G. Kannangara: Synthesis of $\delta$-aminolevulinate by a chloroplast stroma preparation from greening barley leaves. Carlsberg Res. Commun. 42, 459-464 (1977)

7. Gough, S.P., C.R. GiRnth \& C.G. Kannagara: $\delta$-aminolevulinate synthesis in greening barley. 1 . Regulation. In: Proc. 5th Int Congr. Photosyn. V. Chloroplast development. G. Akoyunoglou ed. Balaban International Science Services, Philadelphia, pp. 107-116 (1981)

8. Guerrier-Takada, C., K. Gardiner, T. Marsh, N. PACE, \& S. ALTMAN: The RNA moiety of ribonuclease $P$ is the catalytic subunit of the enzyme. Cell. 35, 849-857 (1983)

9. HALL, T.C.: Transfer RNA-like structures in viral genomes. In: International Review of Cytology. vol 60. G.H.Bourne et al eds. Acad. Press New York, pp. 1-26 (1979)

10. HAREL, E. \& E. NE'EMAN: Alternative routes for the synthesis of 5-aminolevulinic acid in maize leaves II. Formation from glutamate. Plant Physiol. 72, 1062-1067 (1983)

11. Hoven, G., S.P. Gough \& C.G. Kannangara: $\delta$-Aminolevulinate synthesis in greening barley. $V$. The structure of glutamate 1-semialdehyde. Carlsberg Res. Commun. 48, 567-572 (1984)

12. ITZHAKI, R. \& D.M. GiLL: A microbiuret method for estimating proteins. Anal. Biochem. 9, 401-410 (1964)

13. Kannangara, C.G. \& S.P. Gough: Synthesis of $\delta$-aminolevulinate and chlorophyll by isolated chloroplasts. Carlsberg Res. Commun. 42, 441457 (1977)

14. Kannangara, C.G. \& S.P. Gough: Biosynthesis of $\delta$-aminolevulinate in greening barley leaves: Glutamate 1-semialdehyde aminotransferase. 
Carlsberg Res. Commun. 43, 185-194 (1978)

15. Kannangara, C.G. \& S.P. Gough: Biosynthesis of $\delta$-aminolevulinate in greening barley leaves II. Induction of enzyme synthesis by light. Carlsberg Res. Commun. 44, 11-20 (1979)

16. KanNangara, C.G., S.P. Gough \& C.R. GiRnTH: $\delta$-Aminolevulinate synthesis in greening barley. 2. Purification of enzymes. In: 5th Int. Congr. Photosyn. V. Chloroplast development. G. Akoyunoglou ed. Balaban International Science Services, Philadelphia, pp. 117-127 (1981)

17. Kannangara, C.G., S.P. Gough \& D. von WETTSTEIN: Biosynthesis of $\delta$-aminolevulinate and chlorophyll and its genetic regulation. In: Development in plant biology 2. Chloroplast development. G.Akoyunoglou et al. eds. Elsevier/ North Holland, pp. 147-160 (1978)

18. KUNITZ, M.: A spectrophotometric method for the measurement of ribonuclease activity. J. Biol. Chem. 164, 563-568 (1946)

19. Oliver, R.P. \& C. Poulsen: Carlsberg Res Commun. in preparation (1984)

20. POUlSEN, C.: The barley chloroplast genome: Phy- sical structure and transcriptional activity in vivo. Carlsberg Res. Commun. 48, 57-80 (1983)

21. WANG, W.-Y., S.P. Gough \& C.G. KanNangara: Biosynthesis of $\delta$-aminolevulinate in greening barley leaves IV. Isolation of three soluble enzymes required for the conversion of glutamate to $\delta$-aminolevulinate. Carlsberg Res. Commun. 46, 243257 (1981)

22. Wang, W.-Y., D.-D.Huang, D. Stachon, S.P. Gough \& C.G. KanNangara: Purification, characterisation and fractionation of the $\delta$-aminolevulinate synthesising enzymes from light grown Chlamydomonas reinhardtii cells. Plant Physiol. 74, 569-575 (1984)

23. WeBer, M.M. \& A. DANCHIN: Inert Co(III) complexes as reagents for nucleotide binding sites. Methods of Enzymology. 46, 315-321 (1977)

24. Wettstein, D. von, C. Poulsen, R.P. Oliver, S.P. Gough, C.G. KanNangara, B.L. Møller \& D. SIMPSON: Concerted interplay of the chloroplast and nuclear genes in the formation of the photosynthetic apparatus. Proc. XV Int. Congr. of Genetics. New Delhi, India (1983) 